\title{
BENEVOLENT COLLUDERS? THE EFFECTS OF ANTITRUST ACTION ON COLLEGE FINANCIAL AID AND TUITION
}

\author{
Caroline M. Hoxby \\ Working Paper 7754 \\ http://www.nber.org/papers/w7754 \\ NATIONAL BUREAU OF ECONOMIC RESEARCH \\ 1050 Massachusetts Avenue \\ Cambridge, MA 02138 \\ June 2000
}

The author gratefully acknowledges the research assistance of Quincy Evans and helpful conversations with a number of financial aid and admissions officers. The author also thanks Michael Boozer, Janet Currie, William Evans, Jonah Gelbach, William Gentry, Judith Hellerstein, Matthew Kahn, Lawrence Katz, Duncan Thomas, Paul Schultz, Robert Schwab, Giorgio Topa, and Aaron Yelowitz for helpful comments and suggestions. The views expressed herein are those of the author and not necessarily those of the National Bureau of Economic Research.

(C) 2000 by Caroline M. Hoxby. All rights reserved. Short sections of text, not to exceed two paragraphs, may be quoted without explicit permission provided that full credit, including (C) notice, is given to the source. 
Benevolent Colluders? The Effects of Antitrust Action on College Financial Aid and Tuition Caroline M. Hoxby

NBER Working Paper No. 7754

June 2000

\begin{abstract}
The Department of Justice's (DOJ's) investigation of private colleges for price-fixing caused the "Overlap" group of colleges to discontinue their meetings. DOJ alleged that the meetings enabled the colleges to collude on higher tuition and increase their tuition revenue. The colleges claimed that they needed the meeting to implement their policies of basing aid on need and fully covering need. This paper investigates whether the cessation of the meeting caused a break-down of need-based aid policies or whether, as DOJ argued, the meeting was unnecessary for such policies. I also attempt to determine whether the cessation of the meeting affected tuition or tuition revenue. Finally, I examine the question of whether need-based aid is simply redistribution or a method of internalizing externalities among students. Many students would like colleges to maintain policies of need-based aid for others while making exceptions for them, awarding them grants for which they would not qualify based on need. Yet, the same students might prefer a regime of need-based aid, knowing that it would apply to them, because basing aid on need affects colleges' selectivity and diversity.
\end{abstract}

Caroline M. Hoxby

Department of Economics

Harvard University

Cambridge, MA 02138

and NBER

choxby@harvard.edu 


\section{Introduction}

In 1989 through 1991, the Department of Justice (DOJ) investigated a number of private, selective colleges for price-fixing. The investigation eventually focused on the Overlap group of 23 colleges, which met each spring to coordinate calculations of individual students' neediness. The Overlap group comprised about half of the most selective colleges in the United States. ${ }^{1}$ Although the colleges denied the price-fixing allegation, they discontinued the meeting in 1991 and did not resume it even after a federal court of appeals rendered a decision in their favor. This paper presents empirical evidence on the merits of DOJ's case and the colleges' case. In particular, I test whether the elimination of the Overlap meeting caused a breakdown, as the colleges claimed it would, in the colleges' policy of distributing aid solely on the basis of need. I also test whether the cessation of the Overlap meeting lowered tuition or tuition revenue, as DOJ claimed it would. The elimination of the Overlap meeting also provides a rare opportunity to test whether need-based aid is primarily a charitable activity (in which colleges force richer students to participate) or a means of internalizing externalities among students--that is, a means by which colleges create students' preferred environments rather than the environments students would get if they acted individualistically. Many a student would like his college to maintain a policy of giving aid solely on the basis of need for others while exempting him from the policy. But, basing aid on need affects a college's student body and its ability to attract donations. What we would like to test, therefore, is whether the same student prefers a regime of need-based aid, knowing that it would apply to him, to a regime in which all students get the exemptions he seeks for himself.

In short, the paper has two different motivations. First, I want to submit DOJ's allegations and the colleges' responses to empirical analysis, especially because the case broke new ground in antitrust theory. Did the Overlap meeting help colleges maintain policies of need-based aid, as they claimed, or the could colleges maintain such policies without meeting, as DOJ claimed? Was the Overlap meeting instrumental in directing more aid to needy students and increasing enrollment of students from low income and minority backgrounds, as

1 The Overlap colleges are listed in Table 1, as are a number of colleges of comparable selectivity that did not participate in the Overlap meeting. 
the colleges claimed? Did the Overlap meeting allow the colleges to set higher tuition or collect more tuition revenue, as DOJ claimed?

Second, I am motivated by larger economic questions concerning the behavior of selective colleges. There is contention about whether colleges are subjected to strong competitive market forces or have market power. If they have market power, they might use rents they can earn from richer, full-tuition-paying students to give charity to able students from poor backgrounds. In other words, need-based aid might be a mechanism by which colleges pursue their own (perhaps laudable) objectives at the expense of richer students. Alternatively, richer students might sufficiently value the education that a college can offer by aiding needy students that they (the richer students) prefer a regime with relatively less aid for them but more selectivity, diversity, and donations. Even if they have such preferences, their individual actions would undermine need-based aid and some coordination among colleges might be necessary to maintain the regime. Because the antitrust suit forced some colleges to move away from their need-based aid regimes, it allows us to use students' revealed preferences to find out whether need-based aid is just redistribution or a mechanism for internalizing externalities.

Empirically, I use a differences-in-differences approach that relies on differences in the reactions of Overlap and non-Overlap colleges to the antitrust action. The first important source of variation is, thus, the discontinuance of the Overlap meeting. The last meeting held dealt with students who were freshmen in 1990-91. The second important source of variation comes from the fact that, among private colleges with very high selectivity, only about half participated in the Overlap group. Thus, there is a natural control group of colleges that should not have been much affected by the elimination of the Overlap meeting. To test what purpose needbased aid served, I use necessary conditions regarding students' revealed preferences. A necessary condition for need-based aid to be pure redistribution is that students who pay less when need-based aid breaks down should prefer Overlap colleges more after the elimination of the meeting. A necessary condition for need-based aid to have been welfare-improving is that students who are so rich that they do not apply for aid under any regime 
should prefer Overlap colleges less after the elimination of the meeting. ${ }^{2}$

To ensure that the "treatment" and "control" groups are comparable, I consider the origins of the Overlap group and explain why many colleges did not participate even though their admissions pools intersected significantly with those of Overlap colleges. I consider other forces that may have affected colleges, such as fluctuations in the financial markets. I consider various specifications of the treatment and control groups of colleges and of the differences-in-differences equations.

Because the antitrust case is unfamiliar to many readers and it is difficult to understand the predictions to be tested without understanding the case, I give an overview of the case in the next three sections, concentrating on the economics rather than the legal issues. Readers who are familiar with the case may wish to focus on the empirical sections that follow.

\section{An Economist's View of the Antitrust Case - Part One: A Review of Theory}

The antitrust case against the Overlap colleges strained the economic reasoning of both the district and appeals courts. In the courts' defense, it must be said that neither DOJ nor MIT (the only institution to pursue the case) presented a truly coherent economic view. While DOJ and MIT may have been prevented from doing so by legal considerations, such considerations should not constrain us. ${ }^{3}$

\section{A. The Market for College Education}

It is commonly accepted among economists that students are both consumers and producers of college education. More precisely, students consume some goods and services at college and invest in human capital at college. These activities are hard to differentiate and are generally described, in combination, as consumption. Students are producers in that they may facilitate one another's learning.

2 Both of the statements above hold constant the relative tuitions of Overlap and non-Overlap colleges. As we shall see, upholding this ceteris parabis proves easy in practice.

3 One purely legal issue, for instance, was whether colleges' activities could sufficiently be regarded as business activities for antitrust law to apply to them. The district and appeal courts decisions are contained in Bechtle (1991,1992) and Cowen (1993). Law review articles also describe the legal issues quite fully. See Carlson (1995), Kreisler (1991), Morrison (1992), Parent (1994), Petronio (1994), Richmond (1993), Seitz (1995), and Stachtiaris (1994). 
Colleges differ somewhat in their technology for producing education. Highly selective colleges have a technology in which it is peculiarly necessary that students have similar preparation and ability so that they can interact and facilitate one another's learning. Less selective colleges often use a technology in which student interaction is less central, but in which well-prepared and able students are nevertheless valuable because they serve as role models and increase the college's ability to attract good faculty.

If students were purely consumers of education, then colleges would simply offer packages of tuition, goods, and services (of non-student inputs), and students would choose among the packages until the market for college consumption cleared. Similarly, if colleges were purely employers of students as inputs into the production of education, then colleges would simply offer wages and students would, as employees, choose among them. Because students must consume and produce at the same college, colleges' packages of tuition, goods, services, and "wages" must simultaneously clear the markets for students as consumers and as producers.

For now, let us ignore the fact that different students start with different amounts of need, and consider the outcomes we expect to see in the market. We expect a student to generate offers of comparable value at different colleges, although the packages may vary in their composition. One package might contain low tuition and few goods and services; another of equal value might contain high tuition and many goods and services. We expect students who are unusually valuable as producers to earn higher "wages." Some colleges end up having students who are rather homogeneous in their value as producers. Consequently, such colleges provide all of their students with similar packages. This should occur at colleges that use education production technology that works most efficiently when students are combined with peers of equal producing value. Colleges that use other production technologies end up with students who are heterogeneous in their value as producers and, consequently, offer very heterogeneous wages. Their especially valuable students will get approximately the same goods and services as their other students (who contribute much less as producers), so the "wages" of valuable students must differ from those of their fellow students in order to clear the market.

So far, I have referred to students as homogenous or heterogeneous in their value as producers, and this is the correct way to think of the homogeneity or heterogeneity. It is important to keep in mind, however, that two 
students may achieve the same value as producers by combining different qualities. For instance, one student may be a musician while another has slightly higher aptitude. Or, one student may be an athlete while another is from a racial or ethnic group that is sought after for its contribution to social diversity on campus. In practice, aptitude measures are the most widely available and easy-to-understand measures of students' value as producers, and I make use of aptitude measures. Nevertheless, in the discussion that follows (and in ideal empirical work) students are classified by the value as producers, not by one attribute that contribute to their value.

\section{B. Merit Aid}

So far, we have been considering the notional tuition at which a college would be willing to accept any student as a consumer/investor. We have also been considering the notional wage that colleges would be willing to pay each student as a producer. What we observe in the real world are packages that have the same net payments as the notional packages, but have things called tuition and merit scholarships that are not generally identical to notional tuition and wages. (For clarity, the amount that colleges call "tuition" is denominated "list tuition" for the remainder of this section.) The example of highly selective colleges should make the point fairly obvious. These colleges have high notional tuition but also have students who are valuable producers and whose market wages are high. Since they have to strictly ration admission, their list tuition is obviously far below the notional tuition that would clear the market for potential consumers of their education. Their list tuition nets out much of the wage they pay to their typical students, and they manage to charge such list tuition in equilibrium by admitting only students whose market wages are high.

Merit scholarships are the discounts that individual students need to get from each college's list tuition in order to keep the market in equilibrium. (Note that I refer to merit scholarships in a general sense--that is, scholarship that are given for any combination of attributes that make a student valuable as a producer, not just scholarships based on aptitude.) In other words, a set of list tuitions and merit scholarships are market clearing if they correspond to a set of market-clearing notional tuitions and notional wages according to the rule:

$$
\text { list tuition }- \text { merit scholarship }=\text { notional tuition }- \text { notional wage }
$$

or:

$$
\text { notional wage }=(\text { notional tuition }- \text { list tuition })+\text { merit scholarship } .
$$


Notional wages are more likely to show up as merit scholarships (rather than the difference between notional and list tuition) at colleges that do not use admissions to guarantee that their students are relatively homogeneous. At relatively non-selective colleges, notional tuition and list tuition are similar and valuable students can be induced to enroll only by high merit scholarships. At selective colleges where students are relatively homogeneous, there would be little point in setting tuition at whatever it would be for a hypothetical student who did not contribute to the production process and then giving every admittee a very similar merit scholarship. It is worth noting that highly selective colleges not only set list tuition at a level that incorporates their typical student's wages, but that notional tuition minus notional wages for their typical student is often negative. As discussed by Lewis and Winston (1997) and others, most highly selective colleges set list tuition at levels that is below their per-student expenditure, so that a subsidy is required from endowment income for each student. $^{4}$

\section{Banning Merit Scholarships}

Merit scholarships attract valuable students to less selective colleges where they are unusual among their fellow students. Across-the-board tuition subsidies appear in highly selective colleges that would otherwise give each of their relatively homogenous students a similar merit scholarship. The general principle is that merit scholarships are necessary for maintaining equilibrium among heterogeneous students within a college. List tuition and college admissions processes maintain equilibrium between colleges. Differences among students' merit scholarships play the key role in allowing a non-selective college to compete successfully for highly productive students. At highly selective colleges, differences among students' merit scholarships would necessarily be small.

What would happen to a college if it decided not to offer any merit scholarships (but still left itself free to set list tuition, admissions, and goods and services)? A lot would happen to a college that had non-selective admissions and used merit scholarships to manage a heterogeneous student body. Relatively little would change

${ }^{4}$ To close the financial loop, colleges must reliably be able to get donations from students who obtained high value-added from their education. 
at a college that had highly selective admissions, gave across-the-board tuition subsidies in lieu of most potential merit scholarships, and offered only small merit scholarships to handle the small differences among its students. There is a direct parallel for firms. Some firms have technology such that they find it efficient to do little selection in employee recruitment and use bonuses to keep their better employees. Other firms have technology that requires their employees to cooperate, and they find it efficient to recruit selectively, obtain a homogeneous group of workers, and maintain a high degree of wage equality. The former type of firm would be greatly affected by a ban on bonuses; the latter type of firm would not.

\section{Needy Students}

If capital markets for investing in human capital were perfect, then even students from poor families would make optimal investments. Imperfect capital markets may cause needy students to make suboptimal investments in their educations, causing society to experience slower growth--not only because poor students' own investments are suboptimal but because their decisions affect other students' human capital acquisition. Students who underinvest will tend to be under-utilized in their role as producers. They will also give colleges too little incentive to offer education quality and too much incentive to reduce costs. This is the logic underlying intervention for needy students: aid for needy students can promote efficient human capital investments.

\section{An Economist's View of the Antitrust Case, Part Two: Financial Aid and the Overlap Procedures}

In this section, I describe the activities of the Overlap group, along with some background on general financial aid procedures in the United States. ${ }^{5}$

\section{A. Financial Aid}

When a student applies for financial aid, a key calculation is his Expected Family Contribution (EFC). EFC calculations attempt to determine how much a family can afford to pay for a student's college education based on its income, assets, other family members' college expenses, and certain extraordinary expenses such as

${ }^{5}$ Since MIT was the only college to take the case to trial, one must depend largely on its description of the group's activities and goals. DOJ interviewed many college officers who had participated in the Overlap meeting, and transcripts of those interviews suggest that, while they varied in perceptions and sophistication, most of the officers broadly agreed with MIT's presentation. 
health care costs. The federal government uses its calculation of EFC, in combination with the cost of attending the college in which the student enrolls, to determine federal scholarships such as Pell grants and the amount of federally guaranteed loans for which a student qualifies. Non-poor students generally do not qualify for any federal scholarships, so that their federal EFCs are relevant mainly for determining their federal loan capacities. ${ }^{6}$

Colleges use federal EFC calculations diagnostically: EFCs indicate students' needs but they do not determine the institutional scholarships that students receive. A college may choose to offer a student a scholarship, but the scholarship amount will be whatever the college deems appropriate. To pay his tuition (net of any institutional scholarship he has received), a student must rely on his family (which is not always willing to pay the federal EFC), his income from work, and loans. Suppose that a student's family were willing to pay his federal EFC. He might nevertheless decide that he could not afford to attend many colleges because his loans and work requirements would be excessive (or, more precisely, would seem excessive to him). Most colleges do not assure students that, if admitted, they will be able to attend so long as their families are willing to pay their EFCs and they (the students) are willing to work a modest amount and take out modest loans. In fact, many colleges not only do not provide such assurances, they take students' EFCs into account in their admissions decisions, so that they are not plagued by requests for scholarships from students who have been admitted but are unable to afford the cost of attending.

It is worth noting that the federal government encourages colleges to use need-based aid by dictating that any student who receives one dollar of federal aid must only receive need-based aid. This rule effectively puts a tax on any college that make extensive use of merit aid even though the population of students it serves is somewhat needy.

All the colleges in the Overlap group and a number of colleges outside the group voluntarily committed themselves to provide every student they admitted with an assurance that he would be able to afford the cost of attending if his family paid its EFC, he was willing to work a modest amount, and he was willing to take out

${ }^{6}$ For instance, one formula for calculating a student's Pell Grant is the maximum possible Pell Grant minus the student's EFC. 
modest loans. In practice, colleges that made this commitment offered an aid package to every student that covered the entire gap between the cost of attending and his EFC. They offered their neediest students the greatest grants because needy students' capacity for work was not greater than that of less needy students and their capacity for loans was only slightly greater. In short, colleges that made such commitments pledged themselves to give grants to students based on their need.

\section{B. The Ostensible Purpose of the Overlap Group}

Most of the ostensible activities of the Overlap group were a direct result of the colleges' having voluntarily made commitments of the type described above. The principle to remember is that, having made such commitments, students' needs literally became the colleges' financial obligations, not just diagnostic measures the colleges could choose to take into account when awarding scholarships.

First, the Overlap group used a somewhat different formula and more information to calculate EFC than the federal government used. Two of the differences in the formula can be attributed to the fact that the colleges' self-imposed obligations created rules which could be exploited by financially sophisticated parents. All rules make exploitation possible, and students admitted to selective private colleges are disproportionately drawn from families with a high degree of financial sophistication and an unusually high proportion of their income derived from capital. Compared to wage and salary income, capital income is flexible and easy to hide for a short period like the interval when children are attending college. Thus, one difference between the Overlap formula and the federal formula was that the Overlap colleges agreed not automatically to allow capital income losses that were allowed for federal tax purposes. Essentially, the colleges did not want their financial obligations increased by parents who were clever about using tax shelters to hide income.

Capital income is particularly easy to hide if only the custodial parent's income is examined for the calculation of EFC. Both parents in a divorce stand to benefit if they have a settlement that artificially depresses the custodial parent's income during the years in which their children attend college, with a corresponding increase in income or assets outside of this interval. Such arrangements are easy to carry out if the family has substantial capital. Thus, another difference between the Overlap formula and the federal formula was that the Overlap 
formula did not automatically ignore non-custodial parents' income.

The final difference between the Overlap and federal formulas was that the Overlap formula "respected" other colleges' charges to older siblings. Suppose that the oldest child in a family was admitted to Vassar and that, at the time of admission, the family did not qualify for aid but paid the full cost. If the second child in the family was admitted to, say, Princeton the next year, then the family would have been "poorer" because of its payments to Vassar and might well qualify for substantial aid from Princeton. Under the Overlap formula, Vassar would not be obligated to re-calculate need for the first child and start giving that child aid. In other words, Vassar's original obligation was respected and Princeton did not expect Vassar to increase its obligation to the first child because it, Princeton, had admitted the second child and thereby increased the family's potential college expenses. This arrangement reduced the risk exposure of the colleges, which otherwise would have been exposed to considerable variation in their obligation to each student. It also made for administrative simplicity-the alternative would have been negotiations between colleges over each family or multiple rounds of EFC calculations. $^{7}$

The activity of the Overlap group was coordination of EFC calculations, which occurred mainly at a spring meeting. Since the colleges all claimed to be using the same formula, coordination would have been unnecessary if all the colleges had been provided with exactly the same information by parents, if no judgement were required in interpreting parents' responses, and if the colleges had not believed that the visibility of the EFC calculations at the meeting helped maintain the formula (that is, a college that routinely deviated from the formula would have been exposed). At the meeting, students who had been admitted to multiple Overlap colleges were listed, and each student's EFC was agreed upon. In many cases, colleges merely agreed upon a median interpretation of ambiguous information; in other cases, one college had superior information, so its calculation carried more weight. Since one of the key pieces of information for calculating EFC was what the parents were

7 The first round would be the admission of the second sibling to Princeton, with Princeton aid offer based on the family's payments to Vassar. But, the family's new obligations to Princeton would decrease its EFC from Vassar's point of view, generating a increase in Vassar's aid obligation to the family. The family's reduced obligations to Vassar would increase its EFC, generating a decrease in Princeton's aid obligation to the family. And so on.

The colleges believed that such negotiations would be administratively expensive and that the payments would wash out over many families and time. 
paying for their other children's college education, the colleges could use the meeting to confirm parents' reports of what aid they were receiving from other colleges. Discussions rarely revealed that parents had underreported their payments to other colleges.

The Overlap meeting did not actually coordinate colleges' divisions of each student's need-based aid into grants, loans, and other sources of aid, but the meeting did provide an opportunity for colleges to share their ideas about what constituted modest amounts of work and loans. Aid packages did differ in composition among Overlap colleges, so that one college might offer grants equal to 33 percent of a student's total aid, while another college offered grants equal to 40 percent of his total aid. Students could and did use "better" aid packages as leverage to get more grants from competing colleges.

The Overlap meeting provided no enforcement mechanism by which colleges that deviated from the formula could be restrained, and each college individually had to decide whether to commit to covering the gap between the cost of attending and EFC, whether to distribute all or some share of aid purely on the basis of need, and whether to make admissions need-blind. ${ }^{8}$ But, the meeting would have made it difficult for a college to pursue one policy while claiming to pursue another without the subterfuge becoming obvious. In particular, a college that only claimed to be fully covering need or distributing aid on the basis of need would have been unwelcome at the meeting. Such a college would have been depending on the other colleges to lend credibility to the claim that selective, private colleges were accessible to needy students. The worry was that such a college would get the benefit of the claim (a more diverse applicant pool, a reputation for highly principled and efficient use of donors' money) but actually free-ride and pay none of the costs associated with it. In short, the colleges worried about reputational externalities.

In summary, the colleges were concerned that, in the absence of the Overlap formula and meeting, their commitments to fully cover need would be exploited by less needy, more sophisticated parents and their discretion over how to interpret ambiguous parental information would eventually make the calculation of need so subjective that a college could change its policy while claiming not to have done so (making free-riding easy). They

\footnotetext{
${ }^{8}$ In fact, within the Overlap group, only some colleges maintained strictly need-blind admissions.
} 
suggested that if need-based aid became less practicable as a consequence of the antitrust action, they might have to abandon their full coverage of need, their policies of admitting students without regard to need, and their diverse student bodies.

\section{An Economist's View of the Antitrust Case, Part Three: DOJ's Allegations}

It is straightforward to state DOJ's allegations. DOJ alleged that the Overlap meeting allowed participating colleges to raise list tuition and to earn higher tuition revenue.

For a few reasons, it is less straightforward to reconstruct the reasoning behind DOJ's allegations. First, DOJ relied on theory written for firms in which consumers do not produce and employees do not consume, and it did not modify the theory for use with higher education. For instance, wages and prices are separately identifiable when a person consumes at one firm and is employed at another. But, only net prices or net wages are identifiable if a person has to consume and produce at the same firm. Thus, it is not correct to say that a student's receiving different merit aid at different colleges constitutes evidence of market power, even though a standard firm that succeeded in routinely paying lower wages would have to have monopsony power.

DOJ also relied on standard arguments about price fixing and price discrimination without making modifications for higher education. This created practical problems for DOJ. Under standard assumptions (where there is no reason to think that some people are underconsuming or that their underconsumption significantly reduces social welfare), agreements about how to calculate need and agreements to allow some people's payments to depend upon their need would constitute price fixing and price discrimination. Thus, under standard assumption, federal policies would be the primary anticompetitive force in higher education. The federal government is the main coordinator of need calculations, penalizes colleges that ignore a student's need and instead give merit aid, and fixes the tuition paid by tens of thousands of Pell Grant recipients! In other words, federal policy is based on the idea that needy students are excessively price-sensitive when they invest in education, that reducing their price sensitivity will correct their cost-benefit calculations, and that these corrections justify any possible distortions to their human capital investments. The dual argument is that reducing 
needy students' excessive price sensitivity will correct excessive cost- (and quality-) reducing incentives that their behavior would otherwise give colleges, and that these corrections justify any possible distortions to colleges' cost and quality decisions. Such arguments are either valid and justify the federal government's policies or they are invalid. If DOJ were to have admitted the validity of such arguments, then it would have had to admit that needbased aid does not constitute straightforward price fixing and price discrimination. If DOJ were to have denied the validity of such arguments, then it would have had to condemn federal policy in the same breath with which it condemned the Overlap group. DOJ attempted to escape this bind by (1) supporting need-based aid while arguing that the Overlap meeting was unnecessary for administering need-based aid and (2) making only passing, rather than fully argued, appeals to conventional wisdom about price discrimination and price fixing.

Finally, it is hard to reconstruct DOJ's reasoning because DOJ argued that the Overlap meeting constituted per se price fixing. In a stereotypical example of per se price fixing, two firms' representatives are seen meeting regularly and agreeing on prices. In such cases, DOJ is not required to show that the firms use a specific mechanism to raise prices or to show that the prices are actually affected. There is a presumption that price-fixing is going on (based on the idea that there is no other credible reason for the meeting), and DOJ's case is permitted to be more cursory.

\section{A. The Allegation that the Overlap Procedures Helped the Colleges Collude on List Tuition}

DOJ's most straightforward allegation was that the Overlap meeting helped the colleges collude on list tuition. The meeting would have just been a venue since the Overlap group's ostensible activities would not have facilitated such collusion. Coordination of EFC does not require any coordination of list tuition, and the finances of students who paid list tuition were not discussed at the meeting for the simple reason that they did not receive aid or generally submit financial information.

If DOJ was correct, we expect to see an effect of the meeting on the level of list tuition. We might also expect that tuition announcements were made after the Overlap meeting. If non-Overlap colleges did not actively collude but did look for price leadership from the Overlap group, then we would expect to see non-Overlap colleges' tuition announcements also occurring after the meeting. 
B. The Allegation that the Overlap Meeting Allowed to Colleges to Obtain Excessive Tuition Revenue

The key DOJ allegation was that the Overlap meeting allowed the colleges to obtain more tuition revenue than they would otherwise have. This allegation had a few logical parts. First, DOJ alleged that, given the students they were enrolling, the college were getting their students too cheaply. That is, the Overlap meeting allowed the colleges to give their students too little need-based aid and too little merit aid. Second, DOJ alleged that the elimination of the meeting would not cause the neediness of the colleges' student bodies to change.

Let us consider the second part of the allegation first, because it is simpler. DOJ itself argued (in the first part of the allegation) that eliminating the meeting would make the colleges' admissions and aid policies more expensive. Thus, the second part of DOJ's allegation logically required the colleges to have rent (from sources unrelated to any collusion occurring at the Overlap meeting) so that they could stop meeting, keep their policies intact, and just charge each student less. It was also assumed that the colleges would choose their aid policies without being sensitive to the price of those policies. In any case, the question to be answered is clear: would the colleges continue to fully cover need and distribute purely on the basis of need if the prices of these policies rose?

\section{The Allegation that the Overlap Meeting gave Too Little Need-Based Aid to Needy Students}

DOJ alleged that the Overlap formula (and the meeting that enforced it) allowed the colleges to give fewer need-based grants to needy students than they would otherwise have had to give. I have already pointed out that DOJ assumed that colleges would not stop distributing aid solely on the basis of need or stop fully covering need if the Overlap arrangements were discontinued. DOJ's additional claim in defining "otherwise" was, therefore, that the colleges would guarantee aid equal to 100 percent of the difference between their cost of attendance and the federal EFC if the Overlap arrangements did not exist. A large share of the DOJ case was dedicated to showing that the Overlap formula gave students higher EFCs than their federal EFCs. (MIT disputed DOJ's calculations.) Regardless of whose calculations were correct, the line of reasoning is difficult to follow. Colleges were under no obligation to give grants to cover any percentage of the gap between a student's cost of attending and his federal EFC, and DOJ did not pursue colleges that made no commitment to cover the gap. If a college committed to give grants equal to any percentage of the gap between the cost of attending and federal EFC, it 
created an entitlement for needy students that they did not have under federal financial aid policy. DOJ surely would not have tried to prevent colleges from making aid commitments unless the commitments covered 100 percent of the gap between the cost of attending and federal EFC. Moreover, there is no reason to think that greater competition among colleges would lead them to guarantee greater percentages of the gap between the cost of attending and federal EFC. The opposite would appear to be true: under increased competition, we expect colleges to guarantee smaller amounts of the gap, as they try to avoid becoming magnets for more needy, less meritorious students. In any case, the lines were clearly drawn on this issue: DOJ alleged that the end of the Overlap arrangements would make the colleges give more money to needy students and the colleges argued that the end of the Overlap arrangements would make them give more money to non-needy students and less money to needy students.

\section{The Allegation that the Overlap Meeting Let Colleges Give Too Little Merit Aid}

Finally, let us consider DOJ's allegation that the Overlap arrangements allowed the colleges to distribute less merit aid than they would otherwise have had to distribute. Recall that it was in preventing subterfuge (preventing a college from disguising merit aid as need-based aid) that the meetings reinforced colleges' policies to give aid solely based on need. ${ }^{9}$ Let us suppose, then, that the Overlap meetings were effective in making colleges match their aid-giving actions to their announced policies and that no-merit-aid policies would have degenerated in the absence of the Overlap arrangements. Theory suggests that such degeneration would raise merit aid somewhat within the Overlap colleges (in order to handle the small amount of student heterogeneity within each of them), but that a dramatic increase in the average amount of merit aid would not be an equilibrium. DOJ's argument that students at highly selective colleges would receive much more merit aid was probably based on tooliteral application of theories about simple firms. If merit aid were a straightforward wage (and not a net price), then there would be more foundation for DOJ's suggestion that the elimination of the Overlap procedures would equalize merit aid across all colleges, necessitating a dramatic increase in merit aid at highly selective private

${ }^{9}$ The Overlap group did not have any effective sanctions to apply to a college that openly decided to give merit aid. The meeting may have been used as a forum to express disapproval of merit aid, but officers of private, highly selective colleges in the United States have ample opportunities to exchange opinions. 
colleges.

\section{Did the Overlap Procedures Maximize Colleges' Objectives or Students' Welfare?}

DOJ's case and the colleges' response contain a number of predictions that can be tested without understanding the objectives that are fulfilled when a college decides to distribute aid on the basis of need. Nevertheless, the elimination of the Overlap meeting creates a rare opportunity to discover the underlying objectives.

\section{A. Banning Merit Aid}

There are a few possible reasons for banning merit aid. Being highly selective colleges, the Overlap colleges could only hope to save a small amount on grants by banning merit aid. However, they might have saved a lot of administrative effort and have made collusion on list tuition easier, if they were engaging in such collusion.

The alternative reason for a ban on merit aid is that it may help colleges maintain education production technologies in which interaction among students of relatively equal abilities is essential. The reason is that, in the absence of the ban, individual students could not be expected to internalize the effects of their merit aid on their own education. Consider a student who is believed to be a potential "star." If the student wants to attend a college where the education production technology is such that stars are role models or a form of faculty compensation, then he can take a very disproportionate share of the college's aid money and still get the education he wants. But, if the student wants to attend a college where the education production technology requires that he routinely interact with other students of his own ability, the student should not take a very disproportionate share of the college's aid money because he will lower the average ability of his peers and detract from his own education. It is unrealistic to expect a student to internalize the effect of his behavior on the college, especially since he would be glad to take more aid himself if he could be an exception and make every other student remain in the no-merit-aid regime. If forced to choose among regimes, which he knows will apply to him, he may prefer a regime in which a ban on merit aid makes him receive a smaller amount of aid but also guarantees him a group 
of peers whose ability is similar to his own.

\section{B. Need-Based Aid that Maximizes Colleges' Welfare at the Expense of Better-Off Students}

If colleges have sufficient market power, then need-based aid may be pure redistribution. That is, a college's need-based aid program may fulfil societal objectives like helping needy students make optimal investments in human capital, but have no peculiar benefits for non-needy students at the college. In this scenario, the people who run colleges get utility from aiding needy students or fulfilling societal objectives, and they like to spend whatever rent they can earn on this charitable activity. Such colleges might want to overcharge their better-off students in order to have extra income they could use for charitable activities. However, no college could unilaterally engage in such redistribution because students, who in this scenario do not value the charity, would always accept the offer of a college that did not engage in the charity. ${ }^{10}$ In order to engage in redistribution, competing colleges would have to collude on a formula for redistribution. So long as they were able to maintain collusion, they would all have to charge better-off students more. Collusion would be rather difficult to maintain because any college that defected would acquire all of the better-off students. Nevertheless, if the market structure were such that collusion could be maintained, the colleges could earn rent so long as they were willing to spend it on charity to needy students.

\section{Need-Based Aid that Maximizes Students' Welfare}

Now consider a scenario in which need-based aid maximizes students' welfare, even though individual students would like to defect from the regime while holding everyone else to it. In this scenario, a college's giving aid on the basis of need not only fulfils societal objectives but also has peculiar benefits for the students who attend the college. In this scenario, need-based aid attracts able and diverse applicants and allows a college to construct a student body that is more valuable to non-needy students than it could otherwise construct. Needbased aid might also attract gifts to the endowment from private donors who care about improving college access. In short, need-based aid might allow colleges to offer packages of tuition, goods, services, and student body that

${ }^{10}$ When I say that students do not value the charity, I do not mean that students feel no altruism or fail to recognize the societal value of aiding needy students. I mean that students dislike a system of redistribution based on the college one attends rather than a system of redistribution that is society-wide (such as a system of federal taxes and grants). 
would otherwise be unattainable.

This regime would be welfare-maximizing, quite apart from any societal benefits of need-based aid, if all students--including those with higher incomes--preferred the packages that were attainable with need-based aid to the packages that were attainable without it. Even so, this regime would require some coordination if it were to be maintained. The reason is that every student, as an individual, would like defraud the aid system or defect from the regime, while holding all other students to it. A well-off student who gets no aid would like the college to hold constant its student body and its ability to attract gifts, but rebate to him any tuition he pays that supports needbased aid, however indirectly. Similarly, a student who gets some aid would like the college to hold constant its student body and ability to attract gifts, but treat his parents' information more generously. Needless to say, if every student were to defect, need-based aid systems would not exist and neither would the packages that are only attainable with need-based aid.

The difficulty is that students will not internalize the effects of their defection on the stability of a needbased system. Nor, in general, will an individual college officer making a decision about an individual student fully internalize the effects of slightly undermining the need-based aid system. In such a situation, coordination among colleges on the calculation of need can help to maintain need-based aid policies. Coordination makes it hard for a student to purport to be needier than he is and hard for an individual officer to stray from the formula he is supposed to obey. It also prevents colleges from pretending to offer need-based aid, fully cover need, and conduct need-blind admissions if they are not, in fact, pursuing these policies. This helps to assure colleges that their policies will earn rewards in terms of their admissions pool and gifts. Otherwise, there is always a risk to a college that actually pursues need-based aid and fully covers need that its competitors will claim to do the same, free ride on the credibility that the first college's actions gain for the claims, and--by sharing in the rewards without sharing in the costs--prevent the first college from reaping the rewards associated with its policies.

\section{Empirical Strategy and Identification Issues}

The colleges' and DOJ's positions are testable, empirical predictions. I first test whether the 
discontinuance of the meeting caused the financial aid practices of Overlap colleges to become more like those of highly selective colleges that never participated in the meeting. I see whether the end of meeting caused aid to shift from more needy to less needy students or caused fewer needy students to attend.

Second, I test whether the discontinuance of the meeting caused tuition at Overlap colleges to rise more slowly than previously. I look for evidence of collusion or price leadership in the timing of tuition announcements. ${ }^{11}$ I also look for changes in tuition revenue, the total amount spent on aid, and the share of discounts dispensed as individual aid versus across-the-board tuition subsidies.

Finally, I test whether need-based aid is just redistribution or a method of internalizing externalities. The elimination of the Overlap meeting provides us with variation in some colleges' ability to maintain need-based aid regimes. One test of the two scenarios is simply how fast and how quickly need-based aid systems broke down, since colleges have much stronger incentives to unilaterally depart from previously agreed-upon formulas if needbased aid is pure redistribution. Other tests come from students' revealed preferences. These tests are unfortunately biased towards finding that need-based aid is pure redistribution, for the simple reason that students who might be expected to react to the regime change by changing their revealed preferences are unlikely to have fully understood the regime change. In other words, people are likely to react to how the regime change affects them personally but underreact to the regime changes's more general effects.

\section{A. Empirical Strategy}

I use slightly different data in each of the three sections of results (effects on financial aid, effects on tuition, effects of students' revealed preferences), and I therefore discuss the data with the results. The empirical strategy of the three sections is, however, fundamentally the same. It is a difference-in-differences strategy that relies on two sources of variation. First, there is the variation over time that derives from the antitrust action. Specifically, the last Overlap meeting affected students who were freshmen in 1990-91. We expect financial aid, tuition, and revealed preferences to alter for cohorts admitted after the antitrust action, but we expect that the

${ }^{11}$ Some people have suggested that the similarity of tuition charges at highly selective colleges was, in and of itself, evidence of collusion. Such suggestions are confused, since perfect competition would also generate similar prices for similar college education. 
alteration will be gradual rather than a discrete, immediate change. In other words, we expect a change in the trends of aid, tuition, and preferences, not a one-time change in the levels.

The second source of variation comes from the fact that only some highly selective colleges participated in the Overlap group. On the whole, we expect Overlap colleges to have changed their behavior much more than non-Overlap colleges following the antitrust action. In addition, we expect Overlap and non-Overlap colleges to have behaved differently before the antitrust action, and we expect the behavior of the two groups of colleges to have converged after the antitrust action. Table 1 lists the Overlap colleges and control colleges that were selected because they had comparable selectivity. Rather than select the control colleges myself (a process that might introduce bias), I used the classification of colleges by their admissions selectivity from Barron's Profiles of American Colleges for the 1990-91 school year. ${ }^{12}$

In the area of tuition, one might expect Overlap and non-Overlap colleges to have behaved similarly before antitrust action and to have reacted similarly to antitrust action. If markets were competitive before and after the antitrust suit, then tuition of colleges that offer very similar packages would necessarily behave very similarly. Alternatively, if DOJ was correct in alleging that collusion on tuition took place at the Overlap meeting, then the Overlap colleges would have selected (higher) tuition levels that could be supported by noncolluding colleges. However, it is possible that non-Overlap colleges, while not colluding themselves, would have allowed the Overlap group to be the price leader and would have acted much as though they were colluding too.

In addition, the antitrust action greatly increased media attention to tuition of highly selective colleges. For instance, in the three years preceding the announcement that the DOJ was interested in investigating the colleges, there were 41 news stories on the subject of high tuition levels at selective private colleges in major newspapers and news magazines. In the three years following the announcement of DOJ's investigation, there were 704 news stories on the subject. Stories that mentioned the Overlap group comprised only 19 percent of the

12 Any division of colleges among the control groups is necessary somewhat arbitrary. It is preferable to have the arbitrariness come from a source that could not plausibly be endogenous to the antitrust action, such as Barron's. Barron's method of dividing colleges into selectivity groups enjoys wide acceptance and is quite stable from year-to-year. 
increased news coverage. ${ }^{13}$ In other words, all highly selective private colleges experienced a public relations fallout as a consequence of the investigation and felt pressure to hold down rates of tuition increase under intense public scrutiny. Some reporters suggested that, during the investigation, colleges held tuition down, knowing that the lower rates of increase were unsustainable and would imply higher rates of increase during a future period of less scrutiny. Therefore, we might expect the reaction of tuition to antitrust action to be general among highly selective private colleges, not exclusive to the Overlap group, and to show up especially in tuition for 1990-91 and 1991-92.

\section{B. The Basic Specification}

Because the Overlap and non-Overlap colleges may have behaved differently before the antitrust action and may have reacted differently to the antitrust action, the following specification is appropriate:

$$
\begin{gathered}
Y_{j c}=\hat{\mathbf{a}}_{1} \text { cohort }_{c}+\hat{\mathbf{a}}_{2} \text { cohort }_{c} \cdot \text { overlap }_{j}+\hat{\mathbf{a}}_{3} \text { cohort }_{c} \cdot \text { postantitrust }_{c}+\hat{\mathbf{a}}_{4} \text { cohort }_{c} \cdot \text { postantitrust }_{c} \cdot \text { overlap }_{j}+ \\
\boldsymbol{I}_{i} \hat{\mathbf{a}}_{\mathbf{5}}+\hat{\mathbf{a}}_{6} \text { postantitrust }_{c}+\hat{\mathbf{a}}_{7} \text { postantitrust }_{c} \cdot \text { overlap }_{j}++\boldsymbol{X}_{j c} \hat{\mathbf{a}}_{\mathbf{8}}+\stackrel{a}{j c}_{j c} .
\end{gathered}
$$

Specification (1) is appropriate for dependent variables, such as financial aid packages, that are set for a cohort of students. For instance, the cohort of students who were freshmen in the 1990-91 were the last cohort to have their financial aid packages set in the pre-investigation era. The next cohort was the first post-investigation cohort. A nearly identical specification that features school years, rather than cohorts, is appropriate for dependent variables such as tuition that are set for a school year.

The index $j$ designates colleges, $c$ designates cohorts, and $t$ designates the school-year. $Y$ is the outcome of interest. cohort is defined as follows:

$\begin{array}{ccc}-2 & & 1988-89 \\ -1 & & \\ 1 & & \\ 0 & \text { for students who entered as freshmen in } & 1990-91 \\ 1 & & 1991-92 \\ 1 & & 1992-93\end{array}$

and so on for outlying years. For convenience, school years are identically defined in equations where that variable is appropriate. I generally use data for the cohorts who entered their freshmen year between 1984-85 and 1996-97, although in some regressions 1995-96 is the last year for which data are available and in others 1997-98

13 Author's calculations based on Nexis searches of major newspapers and news magazines. 
data are available. I generally omit the two years during which the case was pending (1990-91 and 1991-92), although assigning these years to their respective pre- and post-antitrust regimes does not significantly affect the results. ${ }^{14}$ The variable Overlap is an indicator for a college having belonged to the Overlap group, and postantitrust is an indicator for the cohort or school year (whichever is relevant) being after the discontinuance of the Overlap meeting. $\boldsymbol{I}$ is a vector of college indicator variables, $\boldsymbol{X}$ is a vector of explanatory variables that will be explained below, and $\varepsilon$ is an error term.

Specification (1) allows each college to have its own fixed effect on the dependent variable, which is useful for incorporating essential differences among colleges that are relatively constant--such as differences due to location, offerings, size, undergraduates' living arrangements, and the structure of the institution. Dependent variables are allowed to trend linearly over time, and different trends are allowed for Overlap and non-Overlap colleges both before investigation and after investigation. ${ }^{15}$ The coefficient $\hat{a}_{4}$ records the change in the behavior of Overlap colleges following the discontinuance of the Overlap meeting. Overlap and control colleges are also allowed to shift their intercepts after the antitrust action.

\section{Possibilities for Omitted Variables Bias}

A estimation strategy like that described above may suffer from omitted variable or other simultaneity bias if there are determinants of college behavior which changed coincidentally with the antitrust action and changed more for Overlap than non-Overlap colleges.

It is useful to describe the events that initiated the investigation. On May 2, 1989, the Wall Street Journal published an article that described an Overlap meeting. The meeting was not particularly covert and had, at that time, been held for years without incident. The colleges were dismayed by the Wall Street Journal's portrayal of the meeting as a "smoke-filled room." DOJ began its investigation soon after the article appeared. At one point, DOJ expanded the investigation to include 55 selective private colleges, but this expansion was short-lived

14 The policies for 1990-91 and 1991-92 were set while the case was pending, even though most of the colleges had settled before the 1991-92 school year began.

15 Note that money variables are generally measured in logs, so that it is their percentage growth that is assumed to be constant within a regime. There is a variant on specification (1), described below, for equations in which the effect of parents' income on the aid a student receives is at issue. 
because colleges outside the Overlap group did not commit to covering the gap between the cost of attending and EFC. This lack of commitment meant that the other colleges could not be said to agree on how much a needy student should pay. It also made meetings similar to the Overlap meeting unnecessary. The meeting itself was crucial to DOJ's case because it created a possible locus for tuition collusion and because the idea of a smokefilled room resonated with the public.

Judging from comments of college officers and DOJ staff, the events that precipitated the investigation came as a surprise. So, the initiation of the investigation was probably arbitrary and certainly not prompted by a change in the colleges' policies.

Nevertheless, we might worry about other events influencing colleges that coincide with the timing of the antitrust action. The obvious candidate is the performance of financial markets over the period under consideration. Fluctuations in financial markets produce corresponding fluctuations in endowments, which are a major source of income for most private, highly selective colleges. Following positive shocks to their endowments, colleges might increase their total expenditure on financial aid and decrease the rate of increase in tuition. It is possible that the continued pursuit (rather than the initiation) of the antitrust action was endogenous to the performance of financial markets. The fact that colleges appeared to be rich in 1990 may have increased DOJ's appetite for the investigation. Would DOJ have pursued the investigation just as strongly in the early 1980s, when tuition was rising faster than it was in 1990 but the financial markets made the colleges appear comparatively poor? ${ }^{16}$

There is a possibility of bias from the financial markets only if the fluctuations affected Overlap colleges more than non-Overlap colleges. It is unlikely that bias should occur since the average endowment per student is approximately the same across Overlap colleges and non-Overlap colleges. However, I reduce the possibility of bias from the financial markets by controlling directly for various market indicators. I also try controlling for

16 Some writers have suggested that there was a link between the antitrust investigation and the federal investigation of Stanford University for misuse of federal research grants. There was no logical or practical link between the cases, however. There were not, for instance, data that were relevant to both investigations. If there was any link at all, it was probably just that both investigations were partially spurred by the colleges' apparent wealth. 
actual changes in colleges' investment portfolios in order to take account of cross-section variance in the impact of any given shock. Among the colleges (indeed, among the colleges within each group), there is substantial variation in endowment per student, so that a given change in the financial markets has more impact on some colleges than others.

We also might worry if participation in the Overlap group was a symptom that a college was fundamentally different from other colleges. For instance, if the colleges in the Overlap group were all more selective than non-Overlap colleges, it would be worrisome. Such fundamental differences would probably not cause bias given the differences-in-differences strategy because the results depend not just on differences between the Overlap and non-Overlap colleges, but on differential changes in the behavior of Overlap and non-Overlap colleges that are timed to begin in 1991-92. Nevertheless, fundamental differences between participants in the treatment and control groups is always worrisome. A brief explanation of how the Overlap group was formed is useful because it shows that within the group of colleges that are highly selective, participation in Overlap was somewhat arbitrary.

The Overlap group began with athletics. Long before the advent of a national market for college and nationally selective colleges, colleges began forming themselves into athletic conferences. The athletic conferences were based partly on geography (because of the inconvenience of traveling for games), partly on college size (because of the greater difficulty of forming competitive teams from a smaller student body), and partly on tastes. In the early 20th century, 3 athletic conferences were formed that became the core of the Overlap group: the Ivy League, the Pentagonal League (of Connecticut River valley colleges), and the Seven Sisters League (of women's colleges). Around the same time, other colleges in the United States that would later be highly selective were also joining athletic conferences. In each athletic conference, colleges began to agree on recruiting rules for student athletes, to ensure that athletic competition would remain relatively fair. A number of conferences agreed to restrict or ban athletic scholarships; the Ivy, Pentagonal, and Seven Sisters league all decided to ban them except in the case of need. The three conferences had to adopt rules that were similar 
because they overlapped--this is the origin of the group's name. ${ }^{17}$ Dartmouth played in both the Ivy and Pentagonal leagues. Overlap between the Ivy and Seven Sisters leagues began when Harvard and Radcliffe adopted joint admissions and financial aid. Nearly all athletic conferences adopt joint rules about scholarships, but why did these three conferences begin to talk about aid policies generally while others did not? The reason is that the colleges in three conferences were roughly similar in terms of their academic objectives, selectivity, and the demographics of their students. Although the Overlap colleges were just as similar to a number of colleges outside the three conferences, the Overlap colleges had no forum for discussing financial aid with these other colleges. Moreover, each of the similar colleges outside the group belonged to an athletic conference in which it (the college) was dissimilar in academics from its fellow members and with which it had made scholarship agreements that could not be kept if it were to join the Overlap group. In short, although the Overlap colleges certainly enjoy a degree of similarity which makes their coordination possible, they are fundamentally very similar to a number of colleges outside the group that happen to belong to different athletic conferences, which are somewhat arbitrary by necessity (because of the limited number of games any team can play in a season).

Finally, we might worry that using the control colleges shown in the first part of Table 1 will result in estimates that understate the true effect of the antitrust action. These control colleges directly compete with the Overlap colleges (that is, a significant minority of the students they admit have also been admitted to an Overlap college) and might respond to the individual students whose offers from Overlap colleges changed. To determine whether the estimates understate the true effect of antitrust action, it is useful to examine some non-Overlap colleges that do not directly compete with the Overlap colleges. I considered three additional control groups that contain colleges that are highly selective but have less than 10 percent (in many cases, much less than 10 percent) of their admissions pool admitted to Overlap colleges. The three groups are: (1) those listed in the continuation of Table 1, (2) all private colleges in Barron's "very competitive" category, (3) all public colleges in Barron's "highly competitive" category. For public colleges, I use variables that apply to out-of-state students. I generally

${ }^{17}$ Some people who have not known the true origin of the name have suggested that it was derived from the fact that the colleges had admissions pools that Overlapped. While it is true that the admission pools of the Overlap colleges intersected, their admissions pools also intersected with many non-Overlap colleges. 
show results for only the first of these three groups of colleges, but the results are similar for the two other groups. ${ }^{18}$

\section{The Effects of Antitrust Action on Financial Aid}

Recall that the Overlap colleges claimed that the meeting helped them to achieve their goals of fully covering need and distributing aid solely on the basis of need. DOJ claimed that the meeting was unnecessary for achieving these goals. To test these claims, I need empirical evidence on how colleges were awarding aid before and after the antitrust action. That is, did the slope of the aid function change, giving less aid to the more needy and more aid to the less needy? I also investigate whether antitrust action caused enrollments of needy and minority students to decline, as MIT claimed it would.

To examine aid functions, I need detailed data on students' financial aid packages and their family backgrounds. The National Postsecondary Student Aid Survey (NPSAS) is the best source of such data that covers cohorts both before and after antitrust action and also covers most colleges. The surveys (each of which covers approximately 50,000 undergraduates) have occurred every three years starting in 1986-87, and I use all four available surveys. ${ }^{19}$ As a result, I have data on the freshmen cohorts of 1982-83 through 1995-96. The NPSAS randomly samples students within each college, but does not sample every college every year. It is important to include college fixed effects in the regressions and use standard error calculations that take into account the clusters of students. ${ }^{20}$

I also use NPSAS to examine enrollment of needy students. Colleges report the racial composition of

18 Contact the author for the results.

19 The NPSAS oversamples students at selective colleges. The 1986-87 NPSAS includes 12,253 students at selective colleges, of whom 1,995 are at colleges listed on the first page of Table 1 . The corresponding numbers for the 1989-90 NPSAS are 11,490 and 3,597. The corresponding numbers for the 1992-93 NPSAS are 10,012 and 1,524. The corresponding numbers for the 1995-96 NPSAS are 8,790 and 1,547.

Future versions of this paper will contain a data appendix.

${ }^{20}$ I use the "survey" procedures in Stata, which use information on a survey's stratified and clustered sampling design. In practice, stratified sampling is not important for the NPSAS data in this paper, since most of the colleges with relevant data fall into the same stratum. 
their entire freshman class each year to the Integrated Postsecondary Education Data System (IPEDS), so I use IPEDS data to examine enrollment of minority students. Throughout the analysis, I make use of both individuallevel data (from NPSAS) and institution-level data (mainly from IPEDS). The advantage of the individual data is that they allow one to examine covariances among students' characteristics. The disadvantage is that they suffer from sampling error.

\section{A. The Grant and Aid Functions of Overlap and Control Colleges}

Table 2 shows the relationships between institutional grants and parents' earned income and between institutional aid and parent's earned income. Following the basic differences-in-differences methodology, I allow the relationships to depend on whether a college belongs to the Overlap group and whether the period is before or after the antitrust action. Since the specification differs slightly from the basic specification, I illustrate it here:

$$
\begin{aligned}
& \text { grant }_{i j c}=a_{1} \text { ParInc }_{i j c}+a_{2} \text { ParInc }_{i j c} \cdot \text { overlap }_{j}+a_{3} \text { ParInc }_{i j c} \cdot \text { postantitrust }_{c}+a_{4} \text { ParInc }_{i j c} \cdot \text { postantitrust }_{c} \cdot \text { overlap }_{j}+ \\
& \boldsymbol{I}_{j} \mathbf{a}_{5}+\mathfrak{a}_{6} \text { post antitrust }_{c}+\hat{a}_{7} \text { postantitrust }_{c} \cdot \text { overlap }_{j}+\boldsymbol{X}_{j c} \mathbf{a}_{\mathbf{8}}+\hat{\mathbf{1}}_{j c}+\hat{\mathbf{1}}_{i j c} .
\end{aligned}
$$

Equation (2) is estimated using maximum likelihood Tobit because grants and aid are equal to zero for students who come from families whose income is too high to quality for aid.

The college fixed effects allow each college to have its own basic grant level (the grant for a minimally needy student who receives aid). Equation (2) allows the need-based aid function to have one slope for preantitrust non-Overlap colleges, another for pre-antitrust Overlap colleges, another for post-antitrust non-Overlap colleges, and yet another for post-antitrust Overlap colleges. It also allows Overlap and control colleges' intercepts to shift after the antitrust action. Thus, I should be able to discern changes in the behavior of Overlap colleges relative to the control colleges, as well as general reactions to the antitrust action among all the colleges. All the variables are in constant 1996 dollars, inflated by the Consumer Price Index (CPI).

Figures 1 through 4 shows the relationships of parental income and grants that are analyzed in the regressions reported in Table 2. The left-hand column of Table 2 shows the results for Overlap colleges and control colleges of equal selectivity. The next column shows the results for Overlap colleges and control colleges that do not have much direct competition with Overlap colleges (see the notes below the table). The dependent variable in the two left-hand columns is the grant from the institution received by a student. Grants include those 
that are nominally need-based and merit-based. Thus, I am not recovering the need-based aid function, but the grant function--which may include higher grants to students who are athletes, especially able, from underrepresented groups, and so on. Among non-Overlap colleges before the antitrust action, a student's grant typically fell by 47.3 dollars for every additional 1000 dollars of parents' income. Comparing this estimate to the mean intercept for control colleges (6,050 dollars), this means that a family with income of approximately 140,000 or more usually received zero grants. ${ }^{21}$ Among Overlap colleges before antitrust, a student's grant fell by 73.3 dollars for every 1000 dollars of parents' income. The grant for the most needy students was higher $(9,137$ dollars), and zero grants were typically received by families with income of approximately 140,000 dollars or more. In short, compared to the control colleges, the Overlap colleges' grants were more generous for the most needy and more elastic with respect to parents' income. The estimates just discussed represent average behavior; the grants for the most needy students, for instance, actually vary by college because of the college fixed effects in the equation.

The control colleges apparently did not alter their grant functions much after the antitrust action because the coefficients on the post-antitrust indicator and on the interaction between parents' income and the postantitrust indicator are small and insignificantly different from zero. The Overlap colleges, however, appear to have made their grant functions less elastic with respect to parents' income. Among Overlap colleges after the antitrust action, a student's grant fell by 59.8 dollars for every 1000 dollars of parents' income. The Overlap colleges do not appear to have changed their grants to their most needy students.

The second column of Table 2 uses a control group of colleges that engage in little direct competition with the Overlap colleges. The results are similar to those in the previous column, except that the treatment and control colleges differ slightly more initially. Among non-Overlap colleges before the antitrust action, a student's grant typically fell by 44.8 dollars for every additional 1000 dollars of parents' income. Among Overlap colleges before antitrust, a student's grant fell by 75.0 dollars for every 1000 dollars of parents' income. The estimated

\footnotetext{
${ }^{21}$ Note that tuition and fees are subtracted from parents' earned income to form the independent variables in
} Table 2. 
grant for the most needy students was substantially higher (9036 as opposed to 4381 dollars) in Overlap colleges. The control colleges did not alter their grant functions much after the antitrust action, but the Overlap colleges made their grant functions less elastic with respect to parents' income without significantly altering their grant to the most needy students. Among Overlap colleges after antitrust, a student's grant fell by 59.4 dollars for every 1000 dollars of parents' income.

The remaining two columns analyze aid. Even more than with grants, it is important to remember that institutional aid does not represent total aid, which generally includes federal aid and may include state aid and private aid. The point estimates suggest that Overlap colleges' total aid packages (not just their grants) were more generous to the most needy and more elastic with respect to parents' income. In the third column, we see that Overlap colleges reduced total aid by 80.9 dollars for every 1000 dollars of parents' income, as opposed to 50.9 dollars for every 1000 dollars among the control colleges. The mean intercepts were 10,798 dollars for Overlap colleges and 8,347 dollars for control colleges. The control colleges did not alter their aid functions significantly in response to the antitrust action, but the Overlap colleges reduced the elasticity of their functions without significantly changing aid for their most needy students. In Overlap colleges after the antitrust action, aid fell by 63.4 dollars for every 1000 dollars of parents' income. In the fourth column, I show results for the control colleges that engage in little direct competition with Overlap colleges. The results are similar to those in the previous column, except that the initial differences are larger.

\section{B. Specification Tests}

The results in Table 2 were subjected to a number of specification tests. To produce the estimates shown, I controlled for the interaction between a college's endowment per student and the percentage rate of return on its endowment over the previous three years. Although the coefficient on this variable was significant and had the expected sign (colleges are slightly more generous when they receive a positive wealth shock), controlling for it has a negligible effect on the other coefficient estimates. I obtained similar patterns of estimates when I controlled for other measures of financial markets and colleges' endowment growth, probably because the coefficients of interest depend on differences in how Overlap and control colleges changed their behavior. Since the Overlap and 
control colleges have approximately the same endowment per student, they reacted similarly to fluctuations in the financial markets. In fact, there is a general result in this paper that financial markets and endowments do matter but that they do not affect the coefficients of interest. Therefore, although I control for an endowment growth per student variable in all the tables that follow, I do not discuss the estimated effects of financial markets further.

Also, I obtain similar results to those in Table 2 if I employ, instead of parents' earned income, parents' adjusted gross income from their tax returns, the federal calculation of expected family income, or the natural log of parents' earned income. It would be very useful to see the results of the same exercise with parents' net worth, but the data for net worth calculations are poor. ${ }^{22}$ If I do not exclude the freshman cohorts whose aid was set during the antitrust investigation (1990-91 and 1991-92), the before-after differences colleges are similar. $^{23}$

\section{How Overlap Affected Grants and Aid for Students' with High SAT Scores}

In Table 3, I repeat much of the exercise in Table 2, except that I now allow grants and aid to be functions of students' SAT scores. ${ }^{24}$ I show results for verbal SAT scores since, as I have emphasized elsewhere, verbal scores are considerably more discriminating than math scores for students who apply to highly selective colleges. $^{25}$ I focus on the coefficients for the SAT scores, but it is worth noting that non-Overlap colleges' grant and aid functions become more elastic with respect to parents' income once we take account of their propensity to give more grants and aid to students with high SAT scores. Before and after the antitrust action, control colleges gave students 1,345 dollars of additional grants for every 100 points on the verbal SAT. For every 100 points,

${ }^{22}$ NPSAS income and expected family contribution data come from multiple sources, including federal financial aid records, institutional records, tax returns, parent surveys, and student surveys. Few parents whose net worth is a more important indicator of their need than their earned income actually apply for aid. Tax return information available for these parents also provides little confirmation of their reported assets. A significant minority of families who do not file for aid refuse to report asset information on either the parent and student surveys, the only possible sources for this information from them.

${ }^{23}$ These results can be obtained from the author.

${ }^{24}$ It would also be interesting to see whether the Overlap colleges and their controls give larger grants to athletes, musicians, and underrepresented minorities. I will investigate the last question in future versions of this paper, but the data are inadequate for testing the first two questions.

${ }^{25}$ See Hoxby and Terry (1998). The College Board's published distributions for the two tests show the dramatic difference in discriminating power between the two tests in the score range of 650 and over (on an individual test). 
total aid from these institutions was higher by between 1,013 dollars. Before antitrust action, the Overlap colleges appear to have raised grants only very slightly for higher SAT scores (perhaps not at all--the coefficients are insignificantly different from zero). The point estimates suggest that 100 points on the verbal SAT generated an increase in grants of 303 dollars. After the antitrust action, it appears that the Overlap colleges began giving somewhat larger grants for high SAT scores, although they did not reach the level of grants given by non-Overlap colleges. The point estimates suggest that, after the antitrust action, 100 points on the verbal SAT generated 884 dollars in grants.

If we compare the grant estimates to the aid estimates in the right-hand columns, we see an interesting pattern in the point estimates. First, it appears that prior to the antitrust action, the Overlap colleges gave no additional aid for higher SAT scores. That is, total aid was unrelated to admissions test scores, as it was designed to be. The small grants for higher scores before the antitrust action presumably resulted from the fact that colleges explicitly agreed on students' EFCs in the Overlap meeting, but not on the precise division between grants and other aid. Second, increases in aid for higher SAT scores account for most of the increase in grants for higher SAT scores at Overlap colleges following the antitrust action. That is, need calculations apparently became slightly more generous for students with higher scores.

\section{The Family Background of Students who Enroll}

Table 4 shows an analysis of how enrollment changed in response to the antitrust action. The two leftmost columns use NPSAS data. The other columns use IPEDS data. The specification is given by equation (1). Consider first the results where the dependent variable is the log of parents' earned income. Average parents' income was 99,509 dollars (11.508 log points) at the control colleges of equal selectivity, 73,791 dollars (11.209 $\log$ points) in the group of less selective control colleges, and 76,191 dollars (11.241 log points) in the Overlap colleges. There was no statistically significant time trend in parents' income at control colleges either before or after the antitrust action. At Overlap colleges, however, parents' real earned income was falling by approximately 2 percent a year in the years immediately preceding the antitrust action. That is, the colleges were increasingly enrolling students from lower- and middle-income families. This tendency reversed itself after the antitrust action 
so that, like the control colleges, the Overlap colleges now appear to have no trend in parents' earned income.

Note that the change in Overlap colleges' intercept (the coefficient on the interaction between post-antitrust and Overlap) is approximately the size that allows the Overlap colleges' trend to change after the suit without a jump in their student composition at that time. See Appendix Figure 1 for an illustration.

I obtain the same results if I use parents' adjusted gross income or the federal calculation of expected family contribution. It would be useful to see the results of the same exercise with parents' net worth, but--as mentioned previously--the data for such calculations are poor.

The remaining columns show the effect of antitrust on the percentage of freshman who are black and Hispanic. Not all prospective black and Hispanic students are needy, but they are disproportionately needy. The Overlap colleges also argued that expanding aid to needy families is a key instrument for increasing the percentage of suitable black and Hispanic students in their applicant pools. ${ }^{26}$ In both groups of control colleges, the percentages of students who were black and Hispanic were increasing by, respectively, 0.22 and 0.25 percentage points each year in the years prior to the antitrust action. Prior to the antitrust action, the Overlap colleges were increasing the representation of minorities slightly faster. In the Overlap colleges, the percentages of students who were black and Hispanic were increasing by, respectively, 0.30 and 0.43 percentage points each year. These relative increases in minority representation (relative to the control colleges) were apparently eliminated after the antitrust action, when the Overlap and control colleges both appeared to be increasing their minority representation at the slower rates typical of control colleges before the antitrust action. ${ }^{27}$ The change in Overlap colleges' intercept (the coefficient on the interaction between post-antitrust and Overlap) is approximately

${ }^{26}$ MIT argued that giving "diversity" grants (a type of merit aid) to underrepresented minorities only reallocated the small number of minorities among the selective colleges, whereas giving generous need-based aid raised confidence about access to MIT among minorities and schools serving minorities. An increase in confidence might be necessary because, years in advance of application, minority students have to commit to skill investments that are unusual in their communities if they are to become successful applicants.

${ }^{27}$ College fixed effects, as opposed to--say--a fixed effect for Overlap colleges as a group, are particularly important in the equations for black and Hispanic student representation. The reason is that individual colleges' minorities are disproportionately influenced by local prevalence of minority populations. Stanford, for instance, enrolls a percentage of Hispanic students that is unusual among selective colleges while Yale enrolls a slightly higher percentage of black students than is usual among urban, selective colleges. 
the size that allows the Overlap colleges' trend to change after the suit without a jump in their student composition at that time. See Appendix Figure 1.

\section{E. Summary}

In summary, the elimination of the Overlap meeting apparently did affect financial aid at colleges that had participated. Grants and aid generally became less elastic with respect to parents' income, partly because betteroff parents and students with high SAT scores were found to be "more needy." That is, there is sufficient flexibility in the definition of need to accommodate small but statistically significant changes in actual practice. Probably as a consequence, trends in Overlap colleges towards less well-off, more black, more Hispanic student bodies were partially reversed. At this point, it is unclear whether the Overlap colleges spent more on financial aid as a result of the antitrust action. On the one hand, they gave more grants to better-off students and apparently gave about the same amount to the most needy students. On the other hand, they probably would have had more needy students in the absence of the antitrust action. I investigate total spending on financial aid in the next section.

Though small, the changes in Overlap colleges' behavior are statistically significant and will, if they continue, ultimately have a substantial effect on the colleges' student composition. The data reject dramatic, discrete changes, however, suggesting that the effects of the Overlap meetings eroded gradually. Perhaps gradualism is the reason why the antitrust action does not seem to have had any indirect effects on financial aid in non-Overlap colleges. (This is true, at least, in the data available for this study. Anecdotal evidence and institutions' announcements suggest that significant changes in financial aid practices occurred at both Overlap and non-Overlap colleges for the freshman cohorts of 1998-99 and 1999-2000. Judging from announcements, the most important changes eliminate some of the progressivity in need-based aid functions. $)^{28}$

${ }^{28}$ Colleges are increasingly excluding assets from consideration that only better-off parents are likely to own. They are also making lump-sum swaps of loans for grants, which benefit better-off parents more than poorer parents. Finally, they have reduced their "tax rates" on students' grants from private sources. On the one hand, this is a move towards merit aid. On the other, the reduction in the tax rates may increase students' grant-raising activity from private sources, which might generally reduce student needs. 


\section{The Effects of Antitrust Action on Tuition and Tuition Revenue}

In this section, I examine the effects on antitrust action on tuition, tuition revenue, and related variables.

All of the data come from IPEDS.

\section{A. The Effects on Tuition}

Although it was never one of its primary allegations, DOJ did allege that the Overlap colleges colluded on tuition at their meeting. One simple test of this argument is whether the colleges' announcements of tuition increases give credence to the idea of collusion. I also examine whether non-Overlap colleges waited for Overlap colleges to announce their tuition, in order to learn the prices that been set by collusion.

My data on announcement dates are still incomplete and, therefore, not analyzed formally in this version of the paper. The data available suggest, however, that most colleges have stuck quite close to an habitual announcement date (such as the "first Monday in March" or the "last Wednesday in February") over the entire period. There is no discernable change in announcement behavior, either among Overlap or control colleges, after the elimination of the Overlap meeting. Moreover, several control colleges routinely announce tuition increases in the first week of February, before the spring Overlap meeting and most Overlap colleges' tuition announcements. The variable that appears best able to explain colleges' announcement dates is the date that the college's second term begins. Thus, colleges on a quarter system generally announce earlier than colleges on a semester system, and colleges that have an earlier spring semester generally announce earlier. In short, a preliminary analysis of announcement dates does not support the idea that the meeting was used as a venue for explicit collusion.

Figure 5 summarizes the effects of antitrust action on total fees, a relationship which is statistically analyzed in Table 5. ${ }^{29}$ The four columns on the left of Table 5 show the effects of antitrust action on the log of real tuition and total fees. The specification is equation (1) and the notes accompanying the table contain other details. Prior to the antitrust action, both non-Overlap and Overlap colleges increased their tuition at approximately 4 percent per year. They increased their total fees at the same rate, about 4 percent per year. There are no statistically significant changes in these rates of increase following the antitrust action, although the

\footnotetext{
29 Total fees are tuition, necessary and usual fees, usual room costs, and usual board costs.
} 
signs of the estimates on the interaction between school year and post-antitrust hint that there may have been a slowing down of tuition and fee increases among all colleges after the anti-trust action that was too small to be statistically significant. (All of the point estimates for changes in the growth rates of tuition and fees are small. Even if all of the standard errors were smaller, the conclusions would not be dramatically different.)

A visual examination of total fees, such as may be obtained from Figure 5, suggests that all selective private colleges, both Overlap and control, slowed tuition growth during the investigation (1990-91 and 1991-92). A specification that allows just these two years, rather than the entire post-investigation period, to have different rates of tuition increase produces weak evidence that all colleges' tuition increases were about 0.8 percentage points lower in these two years. ${ }^{30}$ There is no evidence that Overlap colleges slowed their tuition more than control colleges. In short, the antitrust action did not significantly affect rates of tuition increase, although there may have been a small, temporary slowdown among all colleges during the prosecution of the case.

\section{B. The Effects on Tuition Revenue}

Figure 6 and the remaining columns of Table 5 examine tuition revenue. ${ }^{31}$ Tuition revenue was the core of DOJ's case in that it claimed that the primary effect of the Overlap meeting was to give too little aid to students, thus increasing the tuition revenue for any given level of tuition. Note that tuition revenue is on a perstudent basis because some colleges were expanding their cohort sizes over the period.

Prior to the antitrust action, Overlap and control colleges were increasing their tuition revenue slightly less quickly than their tuition. The rate of growth was about 3.6 percent in control and Overlap colleges (which do not have a statistically significantly different rate of growth than control colleges). There is a hint of a slowdown in the growth of tuition revenue among all colleges, as there was in tuition itself. However, this slowdown is not statistically significant, even if I attempt to isolate the years in which the case was pending.

30 This evidence is weak because the coefficients are significant at only the 20 percent level.

31 This is an estimate of tuition revenue from undergraduates. For some colleges, the amount is easy to estimate. For universities, an effort is made to remove graduate and professional students and tuition they pay, based on detailed data in IPEDS. 
Also, the point estimates have the "wrong" signs for a typical price-fixing story. ${ }^{32}$ There are no statistically significant differences between control and Overlap colleges.

\section{What has "Given" to Allow Aid to Change?}

How does one square the result that the antitrust suit affected financial aid at Overlap colleges but did not change their tuition or tuition revenue? The financial aid estimates suggest that the basic grant was not reduced, so transfers from individual poor students to individual middle-income students do not square the accounts. Given that tuition did not change, transfers from individual well-off students to individual middle income students cannot square the accounts. Furthermore, tuition revenue per student apparently did not change, so colleges did not simply "eat" the costs of the changes in financial aid. This leaves 3 remaining possibilities: (1) that shifts in the composition of student bodies towards richer students made up for the changes in the treatment of individual students , (2) that colleges actually found funds to increase per-student expenditure on grants, but that vagaries of accounting made the grants show up as tuition revenue, and (3) that colleges cut college-wide subsidies per student (cut the quality of services and goods in their packages without commensurately cutting tuition). Table 6 investigates the possibilities (2) and (3).

The two left-hand columns of Table 6 show that per-student expenditures on grants increased almost onefor-one with total fees in both Overlap and control colleges. Per-student expenditures on grants appear not to have reacted to the antitrust action, just as total fees did not react. College-wide tuition subsidies are shown in the two right-hand columns of Table 6. They are defined as expenditures on undergraduate instruction, goods, and other services minus the revenues that undergraduates would pay if they all paid full tuition and fees. The college-wide subsidies increase at between 3.3 and 3.8 percent a year in both Overlap and control colleges and do not appear to have reacted to the antitrust action.

Therefore, the weight of the evidence suggests that changes in the composition of student bodies bore the weight of the changes in financial aid. The need to control the composition of their student bodies may be the

${ }^{32}$ That is, the signs of the point estimates suggest that the Overlap colleges increased their tuition revenues less quickly than the control colleges before the antitrust action and more quickly than the control colleges after the antitrust action. 
reason why several Overlap colleges backed away from fully need-blind admissions after the antitrust action. Early decision policies (as opposed to early action policies) also help colleges control the composition of their student bodies and prevent students from using multiple financial aid offers to get a more favorable "need" calculation. Most early action policies in the Overlap and control colleges have been replaced by early decision policies.

\section{Is Need-Based Aid Just Redistribution?}

The antitrust action provides us with an unusual opportunity to learn about the purpose fulfilled by needbased aid among selective colleges. The tests are made straightforward because there is significant evidence that antitrust action made need-based aid less progressive in Overlap colleges, evidence that the antitrust action did not much affect the basic grants and aid given to the most needy students, and little or no evidence that the antitrust action affected tuition or college-wide tuition subsidies (the packages of goods and services received for any given tuition). Thus, the tests can focus on students' revealing their preference between Overlap and non-Overlap colleges before and after the antitrust action. To examine students' revealed preferences, I use both individual students' choices among colleges to which they were admitted and colleges' statistics on the students they admit and the students who accept their offers of admission. I focus on two necessary conditions. First, if need-based aid is purely redistribution that does not enhance the welfare of all students, then middle-income students who benefit from the decrease in progressivity should prefer Overlap colleges more after the antitrust action. Second, if need-based aid enhances the welfare of all students at a college (that is, it is not just a general social good but a club good whose benefits to the club exceed its costs), then high-income students who cannot expect to get any aid (even when a need-based aid system erodes) should prefer Overlap colleges less after the antitrust action. Their reaction will, however, be limited by their ability to perceive the difference in the college's student body and policies. Since these changes have been gradual, we expect this test to be biased against finding that need-based aid enhances the welfare of all students.

It is helpful to summarize revealed preference arguments in tables that demonstrate the importance of the 
two tests just named. Tests based on the first necessary condition are in bold characters. Tests based on the second necessary condition are in italics. Some less determinative tests are also shown for clarity. 
individual students choosing between Overlap and non-Overlap colleges to which they have been admitted students from low income families who are eligible for financial aid

students from middle income families who are eligible for financial aid (and are not on the margin of being eligible)

students from high income families who are not eligible for any financial aid (and are not on the margin of being eligible)

need-based aid supported by the Overlap arrangements...

...was simply redistribution

little or no effect

(though probability of admission may have change)

probability of choosing an Overlap college rises after antitrust action

no effect ...enhanced the welfare of all students

probability of choosing an Overlap college falls after antitrust action

ambiguous

probability of choosing an Overlap college falls after antitrust action institutional statistics on differences between the class that was admitted and the class that accepted the offer of admission

black students and hispanic students (proxies for students from low income families)

students who attended private secondary schools (proxy for students from high income families)

students who do not receive any financial aid

financial aid recipients

average financial aid award

need-based aid supported by the Overlap arrangements...

...Was simply redistribution $\quad$...enhanced the welfare of all students

little or no effect

no effect

no effect

in Overlap colleges, acceptance rate among admittees may fall slightly among low-income aid recipients, but should rise among middle-income aid recipients

ratio of average award among acceptees to average award among attendees should rise in Overlap college after antitrust action acceptance rate among admittees falls in Overlap colleges after antitrust action

acceptance rate among admittees should fall in Overlap colleges after antitrust action

acceptance rate among admittees should fall in Overlap colleges after antitrust action

ambiguous

ambiguous

Table 7 shows estimates based on the decision of students in the NPSAS 1987-87 and NPSAS 1995-96

who were asked about the colleges to which they been accepted as well as the college they chose. Because only a limited number of observations are available, the dependent variable is an indicator for whether a student chose an 
Overlap college from the set of colleges to which he had been accepted, given that he had been accepted by at least one Overlap and one non-Overlap college. Optimally, one would like to estimate more specific choices, but this is not possible in the available data. Students are divided into three groups: low income (parents' combined income less than 30,000 dollars), high income (those who never receive much need-based aid, with parents' combined income greater than 140,000 dollars), and middle income who are likely to receive some aid (parents' combined income greater than 50,000 and less than 100,000 dollars). Students in all income groups are slightly more likely to accept an offer from an Overlap college. There are no statistically significant changes after antitrust action in the probabilities of low- and high-income to accept Overlap colleges' offer. Thus, there is no support for or violation of the necessary condition for need-based aid being welfare-enhancing for all students. This is not surprising given the low probability that high-income students would have perceived colleges' changing financial aid regimes. However, middle-income students are about 6 percent less likely to accept an Overlap colleges' offer after the antitrust action. This result is statistically significant and is a violation of the necessary condition for need-based being pure redistribution.

Table 8 shows estimates based on colleges' statistics regarding the students they admit and the students who accept their offers of admission. [These data are still incomplete. Some colleges' data are missing.] Because these data are based on populations, they can support the specification given by equation (1). Acceptance rates are generally rising in all Overlap and control colleges. They are rising slightly faster in Overlap colleges among students who are black, are Hispanic, attended private school, or did not receive any financial aid. However, none of these acceptance rates responded significantly to the antitrust action. Thus, I again find no support for or violation of the necessary condition for need-based aid being welfare enhancing.

The ratio of the average aid award among acceptees to the average aid award among admittees shows which type of financial aid recipient is refusing a college's offers--low-income students (who get a lot of aid) or middle-income students (who get little aid). If the ratio increases, a higher share of low-income students than of middle-income students are accepting their offers, and vice versa. If the ratio is equal to 1 , then acceptance is equally likely among low-income and middle-income students. There is no trend in this ratio in control colleges, 
either before of after antitrust action. However, the ratio is increasing by 0.05 every year in Overlap colleges, both before and after the antitrust action. This suggests that Overlap colleges are increasingly unattractive to the middle-income students they admit. This trend was not at all reversed by the antitrust action (the point estimate has the wrong sign) even though there is evidence that financial aid grew more generous for middle-income students. This is a violation of the necessary condition for need-based aid to be pure redistribution.

In summary, the data do not support the notion that need-based is pure redistribution, since Overlap colleges gave more generous grants to middle-income aid recipients after the antitrust action but these students' revealed preferences did not move towards Overlap colleges. If anything, they moved slightly towards control colleges. It is perhaps too early to use revealed preference data to assess richer students' reactions to the changes in colleges wrought by the antitrust action. These students have not reacted significantly, but the changes that have occurred (as recorded in Tables 2-4) may be too small for them to perceive.

\section{Conclusions}

I find evidence that antitrust suit did affect financial aid in Overlap colleges, resulting in aid that was less progressive with respect to parents' income and slightly more sensitive to merit. I find no evidence that the colleges in the Overlap group were colluding to raise tuition, raise tuition revenue, and save expenditures on grants. Students' revealed preferences before and after the antitrust suit do not confirm that need-based aid enhances the welfare of a college's students by internalizing externalites, but revealed preferences do violate conditions necessary for need-based aid to be pure redistribution. This is weak evidence against the argument that need-based aid is simply redistribution (which may have societal benefits) in which colleges can engage because they have market power. Since changes in financial aid have accelerated dramatically in the past two years, additional years of data may, as they become available, give us more evidence about whether need-based aid is efficiency-enhancing. 
References

Barron's Educational Series, Inc., Barron's Profiles of American Colleges, Eighteenth Edition. Hauppage, New York: Barron's Educational Series, Inc., 1991.

Bechtle, Louis C., Chief Judge of the United States District Court for the Eastern District of Pennsylvania, "Memorandum and Order, United States v. Brown University in Providence in the State of Rhode Island and Providence Plantations; the Trustees of Columbia University in the City of New York; Cornell University; the Trustees of Dartmouth College; President and Fellows of Harvard College, Massachusetts; Massachusetts Institute of Technology; the Trustees of Princeton University; the Trustees of the University of Pennsylvania; and Yale University," August 7, 1991.

Bechtle, Louis C., Chief Judge of the United States District Court for the Eastern District of Pennsylvania, "Judgement, United States v. Brown University in Providence in the State of Rhode Island and Providence Plantations; the Trustees of Columbia University in the City of New York; Cornell University; the Trustees of Dartmouth College; President and Fellows of Harvard College, Massachusetts; Massachusetts Institute of Technology; the Trustees of Princeton University; the Trustees of the University of Pennsylvania; and Yale University," September 2, 1992.

Cage, Mary Crystal. "Justice Department Widens Probe of Tuition and Student Aid to 40 Colleges," The Chronicle of Higher Education, September 20, 1989.

Cage, Mary Crystal. "Colleges Under Investigation by Justice Department," The Chronicle of Higher Education, September 27, 1989.

Carlson, Dennis W., and G. Shepherd. "Cartel on Campus: The Economics and Law of Academic Institution's Financial Aid Price Fixing," Oregon Law Review, Vol. 71 (1992), pp. 563-629.

Carlson, Dennis W., Gustavo E. Bamberger, and Roy J. Epstein. "Antitrust and Higher Education: Was There a Conspiracy to Restrict Financial Aid?" NBER Working Paper No. 4998, January 1995.

Clotfelter, C.T. Buying the Best: Cost Escalation in Elite Higher Education. An NBER Monograph (Princeton: Princeton Univ. Press, 1996).

Cowen, N. Circuit Judge of the United States Court of Appeals for the Third Circuit, "Opinion of the Court, United States v. Brown University in Providence in the State of Rhode Island and Providence Plantations; the Trustees of Columbia University in the City of New York; Cornell University; the Trustees of Dartmouth College; President and Fellows of Harvard College, Massachusetts; Massachusetts Institute of Technology; the Trustees of Princeton University; the Trustees of the University of Pennsylvania; and Yale University," September 17, 1993.

Dodge, Susan. "Overlap Group Makes Aid Process Fairer," The Chronicle of Higher Education, October 11, 1989.

Ehrenberg, R. and S. Murphy. "What Price Diversity?: the Death of Need Based Financial Aid at Selective Private Colleges and Universities." manuscript of article (shortened) published in Change. 1993.

Hansman, H. and A. Klevorik. Competition and Coordination in Markets for Higher Education, New Haven: Yale University Press, 1993. 
Hoxby, Caroline, and Bridget Terry. "Explaining Rising Wage and Income Inequality Among the CollegeEducated," NBER Working Paper No. , 1998.

Jaschik, Scott. "Antitrust Agreement Will Not Bring Lower Tuition Rates," The Chronicle of Higher Education, May 29, 1991.

Jaschik, Scott. "Ivy League Agrees to End Collaboration on Financial Aid," The Chronicle of Higher Education, May 29, 1991.

Jaschik, Scott. "Overlap Group Could Survive Ivy League's Agreement to End Collaboration on Financial Aid, Lawyers Say," The Chronicle of Higher Education, June 5, 1991.

Jaschik, Scott. "Colleges Question Effectiveness of Overlap Group," The Chronicle of Higher Education, May 20, 1992.

Jaschik, Scott. "MIT Trial Opens in Philadelphia," The Chronicle of Higher Education, July 1, 1992.

Jaschik, Scott. "Judge Rules MIT Violated Antitrust Law as Member of 23-College Overlap Group," The Chronicle of Higher Education, September 9, 1992.

Jaschik, Scott. "Appeals Court Give MIT Another Chance," The Chronicle of Higher Education, September 29, 1993.

Jaschik, Scott. "Excerpts from Ruling to Return Overlap Case for New Trial," The Chronicle of Higher Education, September 29, 1993.

Jaschik, Scott. "An Ambigous Antitrust Settlement," The Chronicle of Higher Education, January 5, 1994.

Kreisler, David P. "The Antitrust Laws and the Overlap Group," Syracuse Law Review, Vol. 42, No. 1 (Spring 1991), pp. 217-39.

Lewis, E.G. and G.C. Winston. "Subsidies, Costs, Tuition, and Aid in U.S. Higher Education: 1986-87 to 199394." Williams Project on Higher Education Discussion Paper DP-41, 1997.

McPherson, Michael and M. Shapiro. Keeping College Affordable, Washington, D.C.: Brooking Institution Press, 1991.

Masten, Scott E. "Old School Ties: Financial Aid Coordination and the Governance of Higher Education," Journal of Economic Behavior and Organization, Vol. 28, No. 1 (September 1995), pp. 23-47.

Matlock, Thao P. "The Overlap Group," Journal of Law and Education, Vol. 23, No. 4 (Fall 1994), pp. 523-47.

Morrison, Richard. "Price Fixing Among Elite Colleges and Universities," University of Chicago Law Review, Spring, 1992.

Parent, Jennifer L. "Antitrust Law--Antitrust Laws Apply to Universities Jointly Determining Aid Awards for Commonly Admitted Students--United States v. Brown University," Suffolk University Law Review, Spring, 1994.

Petronio, Michael C. "Eliminating the Social Cost of Higher Education: The Third Circuit Allows Social Welfare 
Benefits to Justify Horizontal Restraints of Trade in United States v. Brown University," Georgetown Law Journal, November 1994.

Richmond, Douglas R. "Antitrust and Higher Education: An Overview," University of Missouri at Kansas City Law Review," Spring, 1993.

Rosovsky, H. The University: An Owner's Manual. (New York: W.W. Norton and Co., 1990).

Rothschild, M. and L.J. White, "The Analytics of the Pricing of Higher Education and Other Services in Which the Customers Are Inputs." Journal of Political Economy 103 (1995): 573-586.

----. "The University in the Marketplace: Some Insights and Some Puzzles." M. Rothschild and C.T. Clotfelter, eds. Studies of Supply and Demand in Higher Education. (Chicago: University of Chicago Press for the NBER, 1993).

Salop, Steven C., and Lawrence J. White. "Policy Watch: Antitrust Goes to College," Journal of Economic Perspectives, Vol 5, No. 3 (Summer 1991), pp. 193-202.

Seitz, Julie L. "Consideration of Noneconomic Procompetitive Justifications in the MIT Antitrust Case," Emory Law Journal, Winter, 1995.

Stachtiaris, Theodore J. "Antitrust in Need: Undergraduate Financial Aid and United States v. Brown University," Fordham Law Review, April, 1994. 
TABLE 1

Treatment And CONTROL COLlEGES FOR ANALYZING THE ANTITRUst ACTION

\begin{tabular}{|c|c|c|}
\hline & Treatment & Control \\
\hline $\begin{array}{l}\text { Named in the } \\
\text { Antitrust Suit } \\
\text { or } \\
\text { Equivalent in } \\
\text { Selectivity }\end{array}$ & $\begin{array}{l}\text { Brown University } \\
\text { Columbia University (Columbia College) } \\
\text { Cornell University (endowed colleges) } \\
\text { Dartmouth College } \\
\text { Harvard University } \\
\text { Massachusetts Institute of Technology } \\
\text { Princeton University } \\
\text { University of Pennsylvania } \\
\text { Yale University }\end{array}$ & $\begin{array}{l}\text { California Institute of Technology } \\
\text { Cooper Union* } \\
\text { Harvey Mudd College } \\
\text { Haverford College } \\
\text { Johns Hopkins University } \\
\text { Pomona College } \\
\text { Rice University* } \\
\text { Stanford University } \\
\text { Swarthmore College }\end{array}$ \\
\hline $\begin{array}{l}\text { The Entire } \\
\text { Overlap } \\
\text { Group } \\
\text { or } \\
\text { Equivalent in } \\
\text { Selectivity }\end{array}$ & $\begin{array}{l}\text { All of the Above Plus: } \\
\text { Amherst College } \\
\text { Barnard College } \\
\text { Bowdoin College } \\
\text { Bryn Mawr College } \\
\text { Colby College } \\
\text { Middlebury College } \\
\text { Mount Holyoke College } \\
\text { Smith College } \\
\text { Trinity College } \\
\text { Tufts University } \\
\text { Vassar College } \\
\text { Wellesley College } \\
\text { Wesleyan University } \\
\text { Williams College }\end{array}$ & $\begin{array}{l}\text { All of the Above Plus: } \\
\text { Bates College } \\
\text { Claremont McKenna College } \\
\text { Colgate College } \\
\text { Davidson College } \\
\text { Duke University } \\
\text { Georgetown University } \\
\text { Hamilton College } \\
\text { Northwestern University } \\
\text { Oberlin College } \\
\text { The College of William and Mary } \\
\text { University of Chicago } \\
\text { Wake Forest College } \\
\text { Washington University } \\
\text { Washington and Lee University }\end{array}$ \\
\hline
\end{tabular}

*Cooper Union and Rice University have unusual tuition policies for highly selective, private colleges. Nevertheless, if they are allowed to have individual intercepts in the estimation (as are all colleges), their behavior is not unusual for colleges in their group. Therefore, I always include them in the estimation, although I sometimes report a mean intercept for the control group that excludes Cooper Union and Rice. 
TABLE 1 CONTINUED

AdDitional Control Colleges For ANALYZING THE ANTITRUST ACTION

1st Slightly Less Selective Control Group

Bennington College

Brandeis University

Bucknell University

Carleton College

Carnegie Mellon University

Case Western Reserve University

Colorado College

Colorado School of Mines

Franklin and Marshall College

Grinnell College

Kalamazoo College

Kenyon College

Lafayette College

Lehigh University
New College (of the University of S.Florida)

Occidental College

Reed College

Rensselaer Polytechnic Institute

Rose-Hulman Institute of Technology

St. John's College

St. Olaf College

Stevens Institute of Technology

Worcester Polytechnic Institute

Union College

University of Dallas

University of Notre Dame

University of Rochester

University of the South 
TABLE 2

THE EFFect of ANTITRUSt Action on the Relationship BETweEn FinANCIAL Aid AND PARENTS' INCOME

\begin{tabular}{|c|c|c|c|c|}
\hline \multirow[b]{2}{*}{$\begin{array}{l}\text { [(parents' income)-(tuition \& fees)] } \\
\text { (thousands of 1996\$) }\end{array}$} & \multicolumn{2}{|c|}{$\begin{array}{l}\text { grant from the institution } \\
\text { (1996 dollars) }\end{array}$} & \multicolumn{2}{|c|}{$\begin{array}{l}\text { total aid from the institution } \\
\text { (1996 dollars) }\end{array}$} \\
\hline & $\begin{array}{l}-47.290 \\
(8.758)\end{array}$ & $\begin{array}{l}-44.789 \\
(9.875)\end{array}$ & $\begin{array}{l}-50.938 \\
(5.049)\end{array}$ & $\begin{array}{l}-69.606 \\
(7.485)\end{array}$ \\
\hline $\begin{array}{l}[(\text { parents' income }) \text {-(tuition \& fees })]^{*} \\
\text { Overlap }\end{array}$ & $\begin{array}{l}-25.979 \\
(11.051)\end{array}$ & $\begin{array}{l}-30.218 \\
(12.496)\end{array}$ & $\begin{array}{r}-29.979 \\
(6.545)\end{array}$ & $\begin{array}{l}-28.549 \\
(8.381)\end{array}$ \\
\hline $\begin{array}{l}{[(\text { parents' income)-(tuition \& fees })]^{*}} \\
\text { post-antitrust }\end{array}$ & $\begin{array}{l}-1.689 \\
(3.087)\end{array}$ & $\begin{array}{l}-1.985 \\
(2.704)\end{array}$ & $\begin{array}{l}-1.646 \\
(2.767)\end{array}$ & $\begin{array}{l}-1.767 \\
(2.364)\end{array}$ \\
\hline $\begin{array}{l}{[(\text { parents' income)-(tuition \& fees })]^{*}} \\
\text { Overlap*post-antitrust }\end{array}$ & $\begin{array}{l}15.208 \\
(4.123)\end{array}$ & $\begin{array}{l}17.558 \\
(3.753)\end{array}$ & $\begin{array}{l}19.168 \\
(3.613)\end{array}$ & $\begin{array}{l}19.333 \\
(3.191)\end{array}$ \\
\hline mean intercept for control colleges & $\begin{array}{l}6050.347 \\
(613.415)\end{array}$ & $\begin{array}{l}4381.013 \\
(570.785)\end{array}$ & $\begin{array}{l}8347.464 \\
(454.667)\end{array}$ & $\begin{array}{l}5763.859 \\
(436.624)\end{array}$ \\
\hline mean intercept for Overlap colleges & $\begin{array}{l}3087.012 \\
(802.224)\end{array}$ & $\begin{array}{l}4654.567 \\
(781.265)\end{array}$ & $\begin{array}{l}2450.234 \\
(573.329)\end{array}$ & $\begin{array}{l}3547.339 \\
(542.578)\end{array}$ \\
\hline post-antitrust & $\begin{array}{c}86.099 \\
(842.390)\end{array}$ & $\begin{array}{c}122.999 \\
(790.236)\end{array}$ & $\begin{array}{l}423.818 \\
(947.704)\end{array}$ & $\begin{array}{c}333.916 \\
(703.049)\end{array}$ \\
\hline post-antitrust*Overlap & $\begin{array}{l}-93.465 \\
(848.428)\end{array}$ & $\begin{array}{l}-118.431 \\
(832.553)\end{array}$ & $\begin{array}{c}-385.283 \\
(1007.459)\end{array}$ & $\begin{array}{l}-316.016 \\
(983.658)\end{array}$ \\
\hline $\begin{array}{l}\text { endowmt per student } * \% \text { growth in } \\
\text { endowmt last } 3 \text { yrs, college fixed effects }\end{array}$ & $\checkmark$ & $\checkmark$ & $\checkmark$ & $\checkmark$ \\
\hline $\begin{array}{l}\text { treatment=colleges in Overlap group } \\
\text { control=colleges of equal selectivity }\end{array}$ & $\checkmark$ & & $\checkmark$ & \\
\hline $\begin{array}{l}\text { treatment=all colleges in Overlap group } \\
\text { control=colleges of lesser selectivity } \dagger\end{array}$ & & $\checkmark$ & & $\checkmark$ \\
\hline number of observations & 4583 & 4508 & 4583 & 4508 \\
\hline
\end{tabular}

Notes: Tobit estimates. Observations are individual students who were freshmen in the school years 1984-85 through 1989-90 or 1992-93 through 1995-96. Standard errors (in parentheses) are estimated allowing for a college-cohort group effect. The Overlap and control colleges are listed in Table 1. Nominal dollars are inflated using the Consumer Price Index.

Specification Notes: Similar results obtain if parents' adjusted gross income, the federal expected family contribution, or the natural log of a parental income measure is used. Similar results obtain if only the colleges charged in the antitrust suit are used, along with the control colleges listed in the uppermost part of Table 1. (Contact the author for results.)

$\dagger$ I show results for the first of the three groups of less selective colleges, but the results are similar for the two other groups of less selective colleges. (Contact the author for results.) The three groups of less selective colleges are: (1) those listed in the continuation of Table 1, (2) all private colleges in Barron's "very competitive" category, (3) all public colleges in Barron's "highly competitive" category. For public colleges, I use tuition that applies to out-of-state students. 
TABLE 3

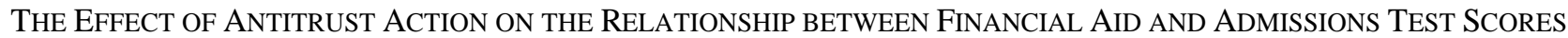

\begin{tabular}{|c|c|c|c|c|}
\hline \multirow[b]{2}{*}{ SATVerbal } & \multicolumn{2}{|c|}{$\begin{array}{l}\text { grant from the institution } \\
\text { (1996 dollars) }\end{array}$} & \multicolumn{2}{|c|}{$\begin{array}{l}\text { total aid from the institution } \\
\text { (1996 dollars) }\end{array}$} \\
\hline & $\begin{array}{l}13.454 \\
(5.943)\end{array}$ & $\begin{array}{l}25.944 \\
(2.194)\end{array}$ & $\begin{array}{l}10.133 \\
(3.880)\end{array}$ & $\begin{array}{l}14.972 \\
(2.645)\end{array}$ \\
\hline SATVerbal*Overlap & $\begin{array}{r}-10.429 \\
(6.678)\end{array}$ & $\begin{array}{l}-23.133 \\
(3.250)\end{array}$ & $\begin{array}{l}-10.010 \\
(3.445)\end{array}$ & $\begin{array}{l}-14.708 \\
(3.100)\end{array}$ \\
\hline SATVerbal*post-antitrust & $\begin{array}{c}0.435 \\
(3.371)\end{array}$ & $\begin{array}{l}1.789 \\
(2.533)\end{array}$ & $\begin{array}{c}0.324 \\
(3.326)\end{array}$ & $\begin{array}{l}1.367 \\
(2.202)\end{array}$ \\
\hline SATVerbal*Overlap*post-antitrust & $\begin{array}{c}5.381 \\
(2.733)\end{array}$ & $\begin{array}{l}9.460 \\
(3.799)\end{array}$ & $\begin{array}{l}3.883 \\
(2.410)\end{array}$ & $\begin{array}{c}3.828 \\
(1.402)\end{array}$ \\
\hline $\begin{array}{l}\text { [(parents' income)-(tuition \& fees)] } \\
\text { (thousands of } 1996 \$)\end{array}$ & $\begin{array}{l}-55.196 \\
(10.293)\end{array}$ & $\begin{array}{l}-52.566 \\
(11.733)\end{array}$ & $\begin{array}{l}-51.716 \\
(9.013)\end{array}$ & $\begin{array}{l}-61.391 \\
(13.447)\end{array}$ \\
\hline $\begin{array}{l}[(\text { parents' income }) \text {-(tuition \& fees })]^{*} \\
\text { Overlap }\end{array}$ & $\begin{array}{l}-25.710 \\
(12.950)\end{array}$ & $\begin{array}{l}-24.919 \\
(9.067)\end{array}$ & $\begin{array}{l}-29.773 \\
(7.194)\end{array}$ & $\begin{array}{l}-26.280 \\
(9.536)\end{array}$ \\
\hline $\begin{array}{l}{\left[(\text { parents' income)-(tuition \& fees) }]^{*}\right.} \\
\text { post-antitrust }\end{array}$ & $\begin{array}{l}-2.278 \\
(2.751)\end{array}$ & $\begin{array}{l}-1.438 \\
(2.612)\end{array}$ & $\begin{array}{l}-1.542 \\
(3.024)\end{array}$ & $\begin{array}{l}-2.242 \\
(2.511)\end{array}$ \\
\hline $\begin{array}{l}{\left[(\text { parents' income)-(tuition \& fees) }]^{*}\right.} \\
\text { Overlap*post-antitrust }\end{array}$ & $\begin{array}{l}14.781 \\
(4.522)\end{array}$ & $\begin{array}{l}14.849 \\
(3.851)\end{array}$ & $\begin{array}{l}19.334 \\
(3.990)\end{array}$ & $\begin{array}{l}20.210 \\
(4.024)\end{array}$ \\
\hline $\begin{array}{l}\text { post-antitrust indicator, post-antitrust* } \\
\text { Overlap indicator (as in Table 2) }\end{array}$ & $\checkmark$ & $\checkmark$ & $\checkmark$ & $\checkmark$ \\
\hline $\begin{array}{l}\text { endowmt per student } * \% \text { growth in } \\
\text { endowmt last } 3 \text { yrs, college fixed effects }\end{array}$ & $\checkmark$ & $\checkmark$ & $\checkmark$ & $\checkmark$ \\
\hline $\begin{array}{l}\text { treatment=colleges in Overlap group } \\
\text { control=colleges of equal selectivity }\end{array}$ & $\checkmark$ & & $\checkmark$ & \\
\hline $\begin{array}{l}\text { treatment=all colleges in Overlap group } \\
\text { control=colleges of lesser selectivity } \dagger\end{array}$ & & $\checkmark$ & & $\checkmark$ \\
\hline number of observations & 4583 & 4508 & 4583 & 4508 \\
\hline
\end{tabular}

Notes: Tobit estimates. Observations are individual students who were freshmen in the school years 1984-85 through 1989-90 or 1992-93 through 1995-96. Standard errors (in parentheses) are estimated allowing for a college-cohort group effect. The Overlap and control colleges are listed in Table 1. Nominal dollars are inflated using the Consumer Price Index.

Specification Notes: The specification notes that accompany the previous table apply to this table also.

$\dagger$ See notes accompanying Table 2. 
TABLE 4

THE EFFECT OF ANTITRUST ACTION ON THE FAMILY BACKGROUND OF STUDENTS WHO ENROLL

\begin{tabular}{|c|c|c|c|c|c|c|}
\hline \multirow[b]{2}{*}{ freshman school year } & \multicolumn{2}{|c|}{$\begin{array}{l}\text { log of parents' } \\
\text { income } \\
\text { (1996 dollars) }\end{array}$} & \multicolumn{2}{|c|}{$\begin{array}{c}\text { percent of } \\
\text { freshmen who are } \\
\text { black }\end{array}$} & \multicolumn{2}{|c|}{$\begin{array}{c}\text { percent of } \\
\text { freshmen who are } \\
\text { hispanic }\end{array}$} \\
\hline & $\begin{array}{c}0.003 \\
(0.011)\end{array}$ & $\begin{array}{l}-0.001 \\
(0.011)\end{array}$ & $\begin{array}{c}0.225 \\
(0.034)\end{array}$ & $\begin{array}{c}0.214 \\
(0.034)\end{array}$ & $\begin{array}{c}0.249 \\
(0.049)\end{array}$ & $\begin{array}{c}0.252 \\
(0.044)\end{array}$ \\
\hline freshman school year*Overlap & $\begin{array}{l}-0.025 \\
(0.011)\end{array}$ & $\begin{array}{l}-0.020 \\
(0.009)\end{array}$ & $\begin{array}{c}0.075 \\
(0.036)\end{array}$ & $\begin{array}{c}0.073 \\
(0.033)\end{array}$ & $\begin{array}{c}0.179 \\
(0.071)\end{array}$ & $\begin{array}{c}0.177 \\
(0.069)\end{array}$ \\
\hline freshman school year*post-antitrust & $\begin{array}{c}-0.002 \\
(0.009)\end{array}$ & $\begin{array}{l}-0.001 \\
(0.009)\end{array}$ & $\begin{array}{l}-0.019 \\
(0.036)\end{array}$ & $\begin{array}{l}-0.023 \\
(0.036)\end{array}$ & $\begin{array}{l}-0.030 \\
(0.066)\end{array}$ & $\begin{array}{l}-0.025 \\
(0.013)\end{array}$ \\
\hline freshman school year*Overlap*post-antitrust & $\begin{array}{c}0.026 \\
(0.012)\end{array}$ & $\begin{array}{c}0.022 \\
(0.011)\end{array}$ & $\begin{array}{l}-0.071 \\
(0.033)\end{array}$ & $\begin{array}{c}-0.070 \\
(0.031)\end{array}$ & $\begin{array}{l}-0.220 \\
(0.092)\end{array}$ & $\begin{array}{l}-0.227 \\
(0.092)\end{array}$ \\
\hline mean intercept for control colleges & $\begin{array}{l}11.508 \\
(0.096)\end{array}$ & $\begin{array}{l}11.209 \\
(0.120)\end{array}$ & $\begin{array}{c}6.041 \\
(0.148)\end{array}$ & $\begin{array}{c}3.875 \\
(0.147)\end{array}$ & $\begin{array}{c}4.198 \\
(0.170)\end{array}$ & $\begin{array}{c}3.857 \\
(0.191)\end{array}$ \\
\hline mean intercept for Overlap colleges & $\begin{array}{l}-0.267 \\
(0.102)\end{array}$ & $\begin{array}{c}0.030 \\
(0.141)\end{array}$ & $\begin{array}{c}0.408 \\
(0.215)\end{array}$ & $\begin{array}{c}2.574 \\
(0.230)\end{array}$ & $\begin{array}{c}0.492 \\
(0.246)\end{array}$ & $\begin{array}{c}0.833 \\
(0.299)\end{array}$ \\
\hline post-antitrust & $\begin{array}{c}-0.042 \\
(0.089)\end{array}$ & $\begin{array}{c}-0.016 \\
(0.097)\end{array}$ & $\begin{array}{c}0.010 \\
(0.198)\end{array}$ & $\begin{array}{c}0.011 \\
(0.195)\end{array}$ & $\begin{array}{c}0.025 \\
(0.226)\end{array}$ & $\begin{array}{c}0.023 \\
(0.254)\end{array}$ \\
\hline post-antitrust*Overlap & $\begin{array}{c}0.102 \\
(0.092)\end{array}$ & $\begin{array}{c}0.068 \\
(0.102)\end{array}$ & $\begin{array}{c}0.108 \\
(0.286)\end{array}$ & $\begin{array}{c}0.110 \\
(0.306)\end{array}$ & $\begin{array}{c}0.297 \\
(0.327)\end{array}$ & $\begin{array}{c}0.306 \\
(0.398)\end{array}$ \\
\hline $\begin{array}{l}\text { endowmt per student } * \% \text { growth in endowmt } \\
\text { last } 3 \text { yrs, college fixed effects }\end{array}$ & $\checkmark$ & $\checkmark$ & $\checkmark$ & $\checkmark$ & $\checkmark$ & $\checkmark$ \\
\hline $\begin{array}{l}\text { treatment=colleges in Overlap group } \\
\text { control=colleges of equal selectivity }\end{array}$ & $\checkmark$ & & $\checkmark$ & & $\checkmark$ & \\
\hline $\begin{array}{l}\text { treatment=all colleges in Overlap group } \\
\text { control=colleges of lesser selectivity } \dagger\end{array}$ & & $\checkmark$ & & $\checkmark$ & & $\checkmark$ \\
\hline number of observations & 4583 & 4508 & 423 & 486 & 423 & 486 \\
\hline
\end{tabular}

Notes: Ordinary least squares estimates. Observations are individual students who were freshmen in the school years 1984-85 through 1989-90 or 1992-93 through 1995-96. Standard errors (in parentheses) are estimated allowing for a college-cohort group effect. Observations in the other 4 columns are college-school years (1984-85, 1986-87, 1988-89, and 1992-93 through 1997-98). The Overlap and control colleges are listed in Table 1. Nominal dollars are inflated using the Consumer Price Index.

Specification Notes: Similar results obtain if parents' adjusted gross income or the federal expected family contribution is used.

$\dagger$ See notes accompanying Table 2 . 
TABLE 5

THE EFFECT OF ANTITRUST ACTION ON TUITION AND TUITION REVENUE

\begin{tabular}{|c|c|c|c|c|c|c|}
\hline \multirow[b]{2}{*}{ school year } & \multicolumn{2}{|c|}{$\begin{array}{c}\text { log of tuition } \\
\text { (1996 dollars) }\end{array}$} & \multicolumn{2}{|c|}{$\begin{array}{l}\log \text { of total fees } \\
\text { (1996 dollars) }\end{array}$} & \multicolumn{2}{|c|}{$\begin{array}{l}\text { log of tuition } \\
\text { revenues per student } \\
\text { (thousands of } \\
1996 \text { dollars) }\end{array}$} \\
\hline & $\begin{array}{c}0.040 \\
(0.010)\end{array}$ & $\begin{array}{c}0.037 \\
(0.011)\end{array}$ & $\begin{array}{c}0.041 \\
(0.010)\end{array}$ & $\begin{array}{c}0.038 \\
(0.012)\end{array}$ & $\begin{array}{c}0.037 \\
(0.009)\end{array}$ & $\begin{array}{c}0.035 \\
(0.012)\end{array}$ \\
\hline school year*Overlap & $\begin{array}{l}-0.009 \\
(0.015)\end{array}$ & $\begin{array}{l}-0.010 \\
(0.015)\end{array}$ & $\begin{array}{l}-0.011 \\
(0.013)\end{array}$ & $\begin{array}{l}-0.010 \\
(0.014)\end{array}$ & $\begin{array}{l}-0.011 \\
(0.013)\end{array}$ & $\begin{array}{l}-0.002 \\
(0.016)\end{array}$ \\
\hline school year*post-antitrust & $\begin{array}{l}-0.013 \\
(0.015)\end{array}$ & $\begin{array}{l}-0.014 \\
(0.016)\end{array}$ & $\begin{array}{l}-0.014 \\
(0.012)\end{array}$ & $\begin{array}{l}-0.015 \\
(0.018)\end{array}$ & $\begin{array}{l}-0.006 \\
(0.013)\end{array}$ & $\begin{array}{l}-0.005 \\
(0.018)\end{array}$ \\
\hline school year*Overlap*post-antitrust & $\begin{array}{c}0.009 \\
(0.018)\end{array}$ & $\begin{array}{c}0.004 \\
(0.019)\end{array}$ & $\begin{array}{c}0.008 \\
(0.016)\end{array}$ & $\begin{array}{c}0.008 \\
(0.016)\end{array}$ & $\begin{array}{c}0.002 \\
(0.018)\end{array}$ & $\begin{array}{c}0.001 \\
(0.018)\end{array}$ \\
\hline mean intercept for control colleges & $\begin{array}{c}9.878 \\
(0.039)\end{array}$ & $\begin{array}{l}9.601 \\
(0.043)\end{array}$ & $\begin{array}{l}10.128 \\
(0.035)\end{array}$ & $\begin{array}{c}9.915 \\
(0.043)\end{array}$ & $\begin{array}{l}10.989 \\
(0.039)\end{array}$ & $\begin{array}{l}10.521 \\
(0.039)\end{array}$ \\
\hline mean intercept for Overlap colleges & $\begin{array}{c}0.048 \\
(0.054)\end{array}$ & $\begin{array}{c}0.050 \\
(0.051)\end{array}$ & $\begin{array}{c}0.047 \\
(0.047)\end{array}$ & $\begin{array}{c}0.052 \\
(0.055)\end{array}$ & $\begin{array}{c}0.060 \\
(0.047)\end{array}$ & $\begin{array}{c}0.063 \\
(0.047)\end{array}$ \\
\hline post-antitrust & $\begin{array}{l}-0.053 \\
(0.050)\end{array}$ & $\begin{array}{l}-0.056 \\
(0.049)\end{array}$ & $\begin{array}{l}-0.038 \\
(0.044)\end{array}$ & $\begin{array}{l}-0.047 \\
(0.046)\end{array}$ & $\begin{array}{l}-0.043 \\
(0.048)\end{array}$ & $\begin{array}{l}-0.045 \\
(0.049)\end{array}$ \\
\hline post-antitrust*Overlap & $\begin{array}{c}0.027 \\
(0.069)\end{array}$ & $\begin{array}{c}0.030 \\
(0.062)\end{array}$ & $\begin{array}{c}0.004 \\
(0.061)\end{array}$ & $\begin{array}{c}0.011 \\
(0.059)\end{array}$ & $\begin{array}{l}-0.013 \\
(0.066)\end{array}$ & $\begin{array}{c}0.004 \\
(0.059)\end{array}$ \\
\hline $\begin{array}{l}\text { endowmt per student } * \% \text { growth in } \\
\text { endowmt last } 3 \text { yrs, college fixed effects }\end{array}$ & $\checkmark$ & $\checkmark$ & $\checkmark$ & $\checkmark$ & $\checkmark$ & $\checkmark$ \\
\hline $\begin{array}{l}\text { treatment=colleges in Overlap group } \\
\text { control=colleges of equal selectivity } \neq\end{array}$ & $\checkmark$ & & $\checkmark$ & & $\checkmark$ & \\
\hline $\begin{array}{l}\text { treatment=all colleges in Overlap group } \\
\text { control=colleges of lesser selectivity } \dagger\end{array}$ & & $\checkmark$ & & $\checkmark$ & & $\checkmark$ \\
\hline number of observations & 517 & 594 & 517 & 594 & 517 & 594 \\
\hline
\end{tabular}

Notes: Ordinary least squares estimates. Observations are college-school years from (1985-86 through 1989-90, and 1992-93 through 1997-98). The Overlap and control colleges are listed in Table 1. Nominal dollars are inflated using the Consumer Price Index.

$\dagger$ See notes accompanying Table 2.

¥ Excluding Cooper Union and Rice University. See Table 1 for details. 
TABLE 6

FURTHER EXPLORATION OF THE EFFECT OF ANTITRUST ACTION ON TUITION REVENUE

\begin{tabular}{|c|c|c|c|c|}
\hline \multirow[b]{2}{*}{ school year } & \multicolumn{2}{|c|}{$\begin{array}{l}\text { log of per-student expenditures on } \\
\text { grants } \\
\text { (thousands of } 1996 \text { dollars) }\end{array}$} & \multicolumn{2}{|c|}{$\begin{array}{l}\text { log of college-wide tuition } \\
\text { subsidies (per-student, } \\
\text { thousands of } 1996 \text { dollars) }\end{array}$} \\
\hline & $\begin{array}{c}0.042 \\
(0.009)\end{array}$ & $\begin{array}{c}0.046 \\
(0.012)\end{array}$ & $\begin{array}{c}0.038 \\
(0.012)\end{array}$ & $\begin{array}{c}0.033 \\
(0.010)\end{array}$ \\
\hline school year*Overlap & $\begin{array}{l}-0.007 \\
(0.013)\end{array}$ & $\begin{array}{l}-0.006 \\
(0.018)\end{array}$ & $\begin{array}{c}0.001 \\
(0.016)\end{array}$ & $\begin{array}{c}0.004 \\
(0.015)\end{array}$ \\
\hline school year*post-antitrust & $\begin{array}{l}-0.008 \\
(0.011)\end{array}$ & $\begin{array}{l}-0.008 \\
(0.014)\end{array}$ & $\begin{array}{l}-0.005 \\
(0.017)\end{array}$ & $\begin{array}{l}-0.004 \\
(0.013)\end{array}$ \\
\hline school year*Overlap*post-antitrust & $\begin{array}{c}0.006 \\
(0.015)\end{array}$ & $\begin{array}{l}0.005 \\
(0.021)\end{array}$ & $\begin{array}{l}-0.002 \\
(0.023)\end{array}$ & $\begin{array}{l}-0.002 \\
(0.020)\end{array}$ \\
\hline mean intercept for control colleges & $\begin{array}{c}1.193 \\
(0.073)\end{array}$ & $\begin{array}{c}0.817 \\
(0.093)\end{array}$ & $\begin{array}{l}2.708 \\
(0.111)\end{array}$ & $\begin{array}{c}2.264 \\
(0.091)\end{array}$ \\
\hline mean intercept for Overlap colleges & $\begin{array}{c}0.219 \\
(0.103)\end{array}$ & $\begin{array}{c}0.595 \\
(0.143)\end{array}$ & $\begin{array}{c}0.019 \\
(0.154)\end{array}$ & $\begin{array}{c}0.463 \\
(0.139)\end{array}$ \\
\hline post-antitrust & $\begin{array}{c}0.007 \\
(0.009)\end{array}$ & $\begin{array}{c}0.009 \\
(0.113)\end{array}$ & $\begin{array}{c}0.010 \\
(0.155)\end{array}$ & $\begin{array}{c}0.007 \\
(0.122)\end{array}$ \\
\hline post-antitrust*Overlap & $\begin{array}{c}0.001 \\
(0.128)\end{array}$ & $\begin{array}{l}-0.009 \\
(0.177)\end{array}$ & $\begin{array}{c}0.006 \\
(0.022)\end{array}$ & $\begin{array}{c}0.008 \\
(0.019)\end{array}$ \\
\hline $\begin{array}{l}\text { endowmt per student } * \% \text { growth in } \\
\text { endowmt last } 3 \text { yrs, college fixed effects }\end{array}$ & $\checkmark$ & $\checkmark$ & $\checkmark$ & $\checkmark$ \\
\hline $\begin{array}{l}\text { treatment=colleges in Overlap group } \\
\text { control=colleges of equal selectivity }\end{array}$ & $\checkmark$ & & $\checkmark$ & \\
\hline $\begin{array}{l}\text { treatment=all colleges in Overlap group } \\
\text { control=colleges of lesser selectivity } \dagger\end{array}$ & & $\checkmark$ & & $\checkmark$ \\
\hline number of observations & 517 & 594 & 517 & 594 \\
\hline
\end{tabular}

Notes: Ordinary least squares estimates. Observations are college-school years from (1985-86 through 1989-90, and 1992-93 through 1997-98). The Overlap and control colleges are listed in Table 1. Nominal dollars are inflated using the Consumer Price Index.

Specification Notes: If I include the school years that contain cohorts admitted both pre-antitrust and post-antitrust, the before-after differences are generally similar but larger.

$\dagger$ See notes accompanying Table 2 . 
TABLE 7

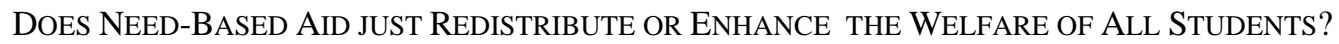
EVIDENCE BASED ON INDIVIDUAL STUDENTS' BEHAVIOR

\begin{tabular}{|c|c|c|c|}
\hline & \multicolumn{3}{|c|}{$\begin{array}{l}\text { dependent variable: indicator for student chose an Overlap college from a set that } \\
\text { included both Overlap and control colleges }\end{array}$} \\
\hline & low-income students & middle-income students & high-income students \\
\hline post-antitrust & $\begin{array}{l}-0.024 \\
(0.057)\end{array}$ & $\begin{array}{l}-0.059 \\
(0.027)\end{array}$ & $\begin{array}{l}-0.030 \\
(0.026)\end{array}$ \\
\hline constant & $\begin{array}{c}0.607 \\
(0.175)\end{array}$ & $\begin{array}{c}0.558 \\
(0.140)\end{array}$ & $\begin{array}{c}0.531 \\
(0.132)\end{array}$ \\
\hline number of observations & 554 & 1708 & 1770 \\
\hline
\end{tabular}

Notes: Probit estimates (of the discrete change in probability, all the independent variable are indicator variables). Observations are individual students who were freshmen in the school years from 1982-83 through 1986-87 or from 199293 through 1995-96. All the Overlap and control colleges listed in the main panel of Table 1 are used. Standard errors are in parentheses.

TABLE 8

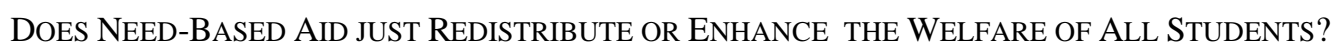

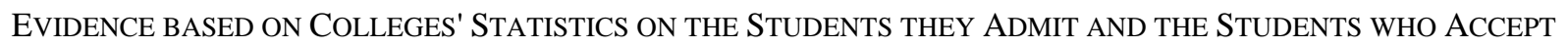

\begin{tabular}{|c|c|c|c|c|c|}
\hline & $\begin{array}{c}\text { Acceptance Rate } \\
\text { among Black } \\
\text { Admittees }\end{array}$ & $\begin{array}{c}\text { Acceptance Rate } \\
\text { among Hispanic } \\
\text { Admittees }\end{array}$ & $\begin{array}{c}\text { Acceptance Rate } \\
\text { among } \\
\text { Admittees who } \\
\text { Attended Private } \\
\text { Secondary } \\
\text { Schools }\end{array}$ & $\begin{array}{c}\text { Acceptance Rate } \\
\text { among } \\
\text { Admittees who } \\
\text { Did Not Receive } \\
\text { Any Financial } \\
\text { Aid }\end{array}$ & $\begin{array}{c}\text { Ratio of (1) } \\
\text { Average Aid } \\
\text { Award among } \\
\text { Acceptees to (2) } \\
\text { Average Aid } \\
\text { Award among } \\
\text { Admittees }\end{array}$ \\
\hline cohort & $\begin{array}{c}0.352 \\
(0.151)\end{array}$ & $\begin{array}{c}0.574 \\
(0.203)\end{array}$ & $\begin{array}{c}0.229 \\
(0.073)\end{array}$ & $\begin{array}{c}0.381 \\
(0.159)\end{array}$ & $\begin{array}{l}-0.016 \\
(0.013)\end{array}$ \\
\hline cohort*Overlap & $\begin{array}{c}0.306 \\
(0.164)\end{array}$ & $\begin{array}{c}0.258 \\
(0.146)\end{array}$ & $\begin{array}{c}0.195 \\
(0.084)\end{array}$ & $\begin{array}{c}0.290 \\
(0.131)\end{array}$ & $\begin{array}{c}0.053 \\
(0.017)\end{array}$ \\
\hline $\begin{array}{l}\text { cohort*post- } \\
\text { antitrust }\end{array}$ & $\begin{array}{c}0.012 \\
(0.213)\end{array}$ & $\begin{array}{c}0.008 \\
(0.246)\end{array}$ & $\begin{array}{c}0.045 \\
(0.053)\end{array}$ & $\begin{array}{l}-0.009 \\
(0.214)\end{array}$ & $\begin{array}{c}0.020 \\
(0.024)\end{array}$ \\
\hline $\begin{array}{l}\text { cohort*Overlap* } \\
\text { post-antitrust }\end{array}$ & $\begin{array}{l}-0.126 \\
(0.198)\end{array}$ & $\begin{array}{l}-0.099 \\
(0.187)\end{array}$ & $\begin{array}{l}-0.013 \\
(0.067)\end{array}$ & $\begin{array}{l}-0.003 \\
(0.220)\end{array}$ & $\begin{array}{c}0.004 \\
(0.018)\end{array}$ \\
\hline $\begin{array}{l}\text { number of } \\
\text { observations }\end{array}$ & 451 & 451 & 451 & 451 & 451 \\
\hline
\end{tabular}

Notes: Ordinary least squares estimates. Observations are college-cohorts of prospective freshmen from 1986-87 to 1996-96. All the Overlap and control colleges listed in the main panel of Table 1 are used. Standard errors are in parentheses. 

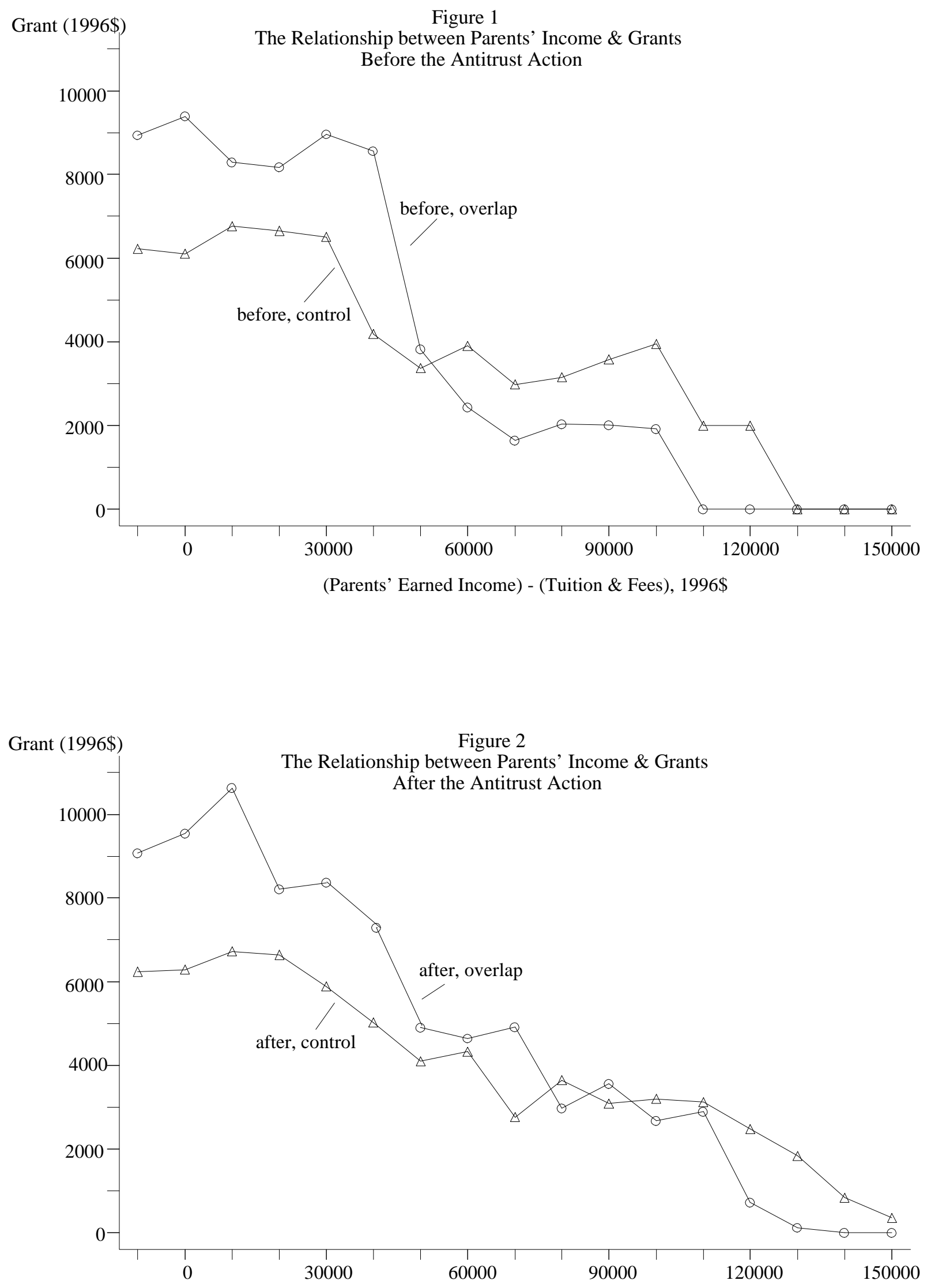

(Parents' Earned Income) - (Tuition \& Fees), 1996\$ 

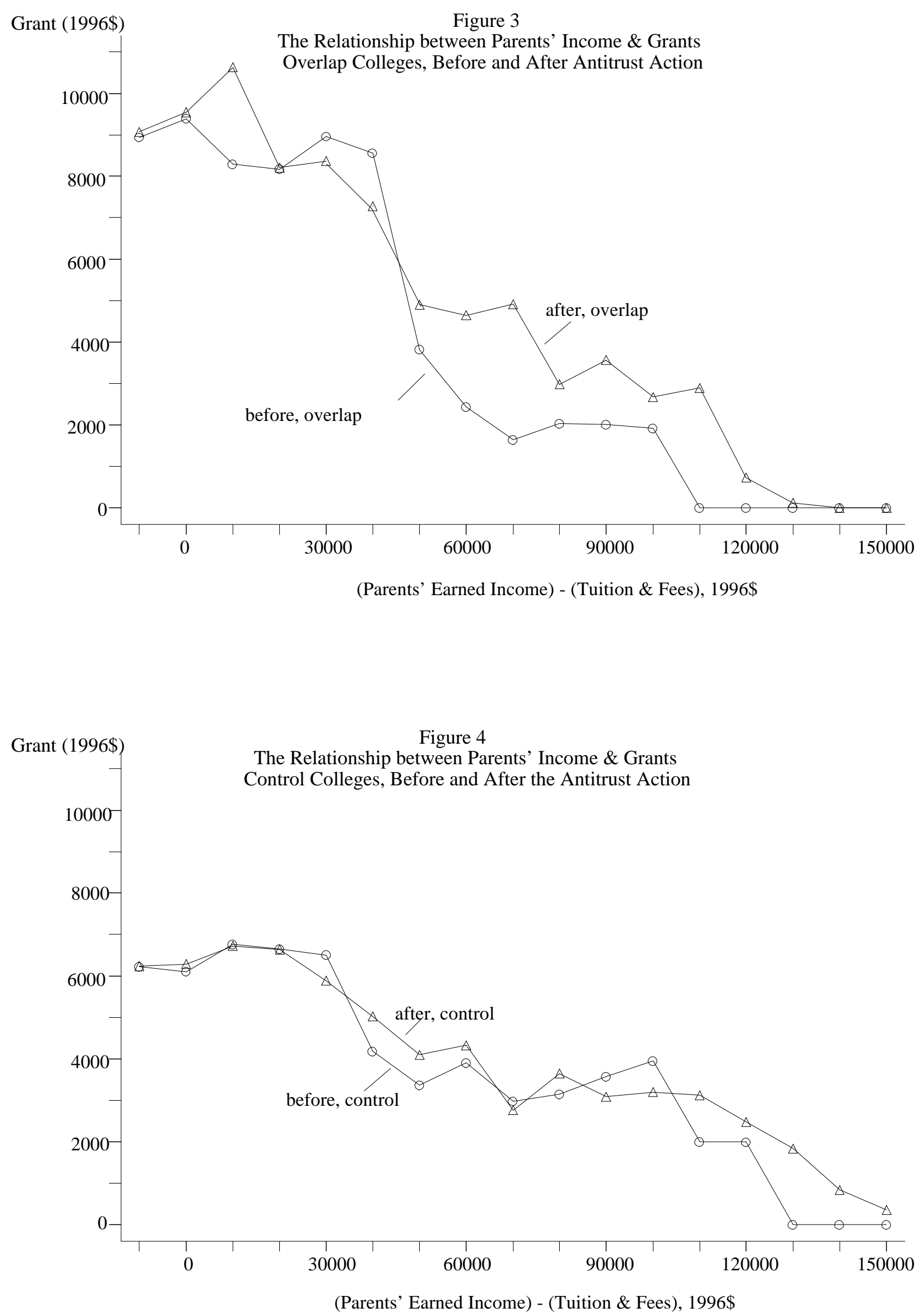
Ln(Tuition \& Fees) (1996\$)

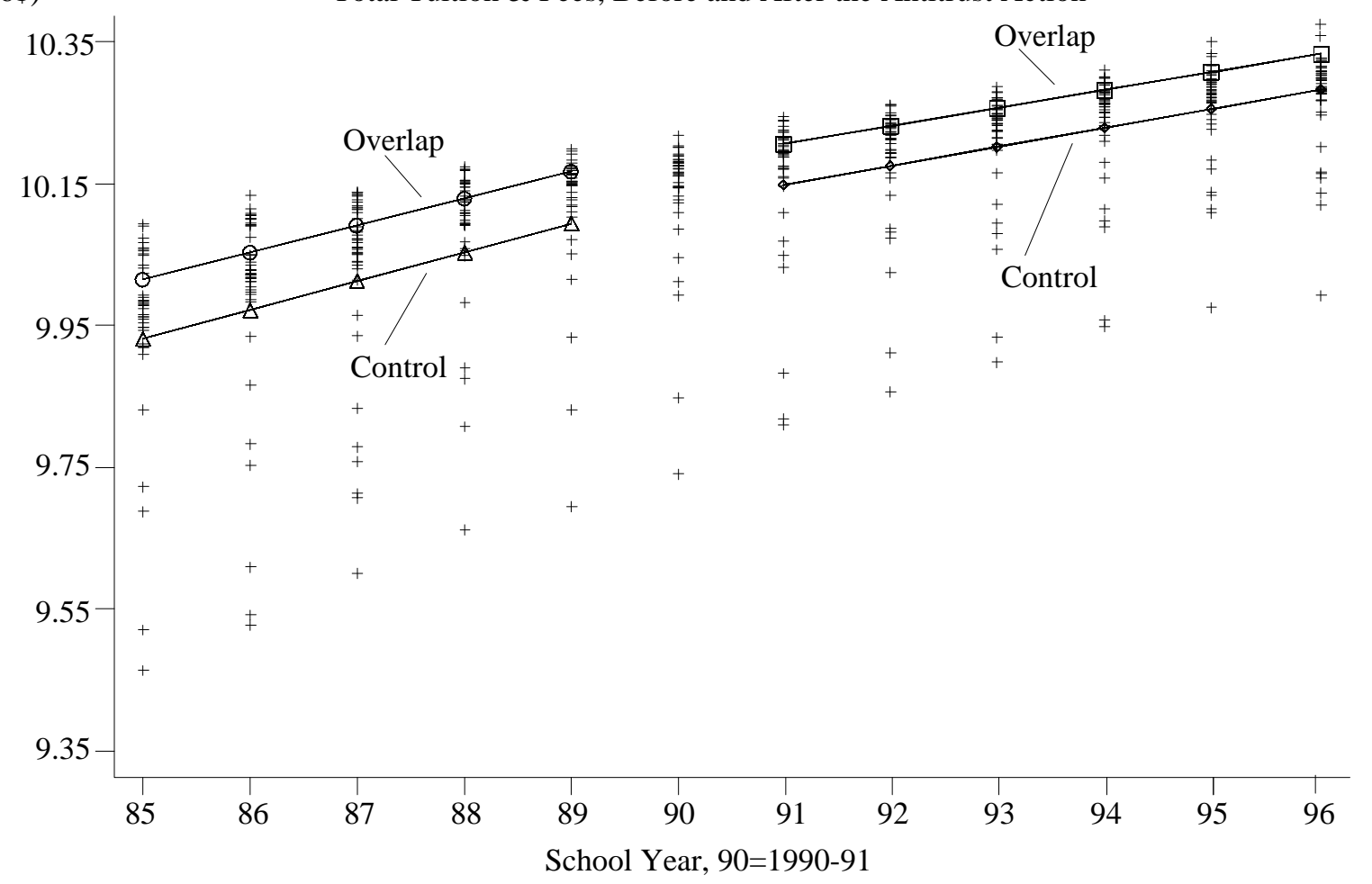

Figure 5

Total Tuition \& Fees, Before and After the Antitrust Action 


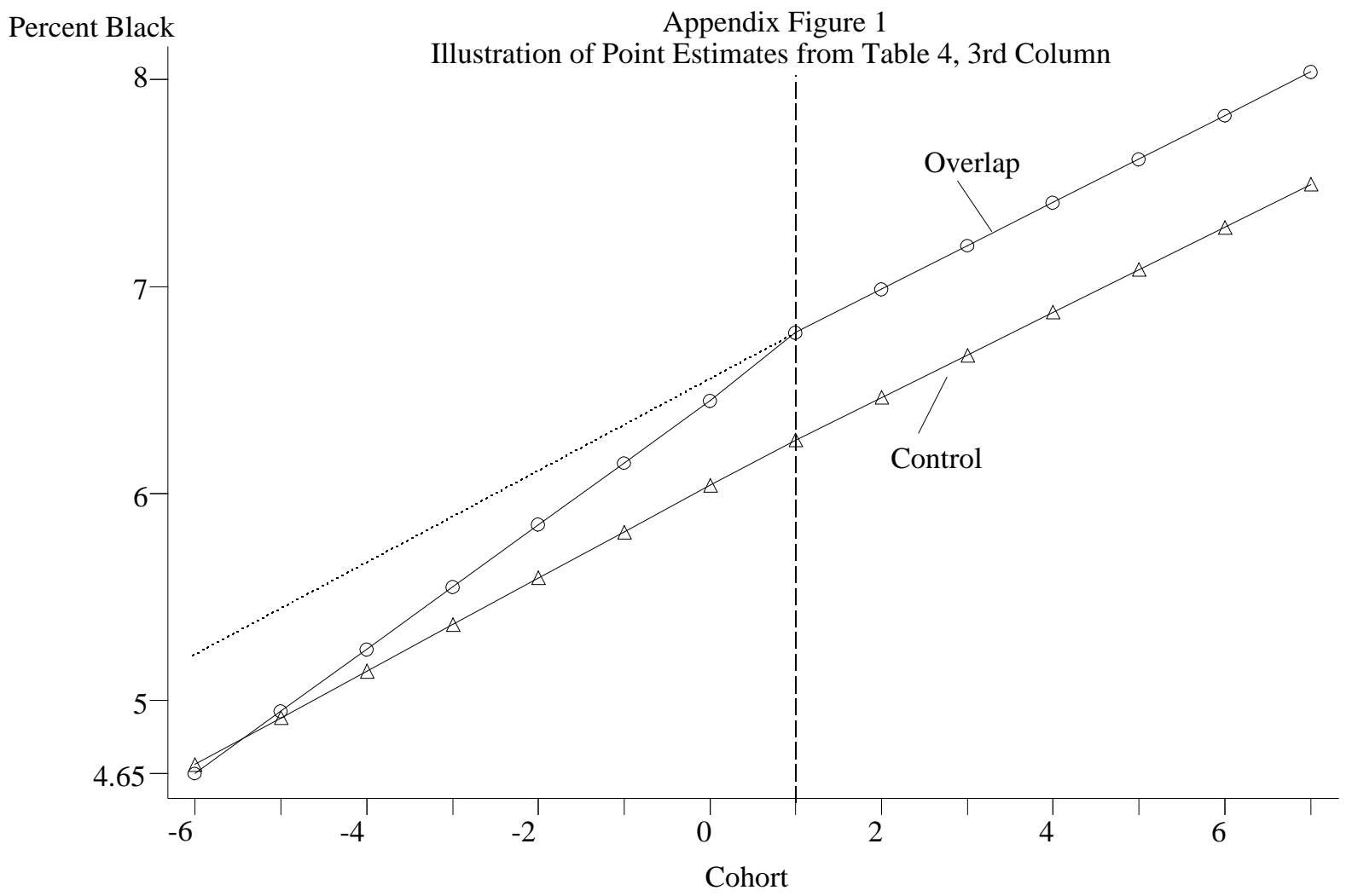

